\title{
The gene Serrate encodes a putative EGF-like transmembrane protein essential for proper ectodermal development in Drosophila melanogaster
}

\author{
Robert J. Fleming, T. Nelson Scottgale, Robert J. Diederich, and Spyros Artavanis-Tsakonas \\ Howard Hughes Medical Institute, Departments of Cell Biology and Biology, Yale University, New Haven, Connecticut 06511 \\ USA
}

\begin{abstract}
Mutations in the third chromosome gene Serrate are shown to display genetic interactions with specific alleles of the neurogenic locus Notch, which encodes a transmembrane protein with epidermal growth factor (EGF) homology. Embryonic lethal Serrate mutations exhibit epidermal and neuronal defects, which are reminiscent of those produced by mutations in the Drosophila EGF receptor homolog gene. We present the molecular cloning of Serrate and show that it encodes two coordinately expressed transcripts from a genomic interval $>30$ $\mathrm{kb}$ in length. The deduced protein product of 1404 amino acids contains a single transmembrane domain and 14 EGF-like repeats. Thus, Serrate represents another member of the group of EGF-containing loci in Drosophila. Whole-mount in situ hybridization analysis reveals complex temporal and spatial patterns of RNA expression consistent with the epidermal and neuronal defects observed in mutant embryos. Finally, we discuss the implications of Serrate function within the context of other cell-surface molecules known to be involved in the differentiation of ectodermally derived tissues.
\end{abstract}

[Key Words: Drosophila; epidermal growth factor; neurogenic genes; ectodermal differentiation]

Received August 23, 1990; revised version accepted September 7, 1990.

Recent embryological, genetic, and molecular evidence indicates that the early steps of ectodermal differentiation in Drosophila depend on cell interactions (Doe and Goodman 1985; Vässin et al. 1985; Technau and Campos-Ortega 1986; Artavanis-Tsakonas 1988; de la Concha et al. 1988; Xu et al. 1990|. Mutational analyses reveal a small group of zygotically acting genes, the socalled neurogenic loci, which affect the choice of ectodermal cells between epidermal and neural pathways (Poulson 1937; Lehmann et al. 1983; Jürgens et al. 1984; Nüsslein-Volhard et al. 1984; Wieschaus et al. 1984). Two neurogenic loci, Notch and Delta, encode transmembrane proteins displaying epidermal growth factor (EGF) homology (Wharton et al. 1985; Kidd et al. 1986; Vässin et al. 1987; Kopczynski et al. 1988); molecular studies have led to the suggestion that they constitute biochemically interacting elements of a cell communication mechanism involved in these early developmental decisions (Fehon et al. 1990).

However, mutational analyses also reveal that the action of the neurogenic genes is pleiotropic and is not limited solely to embryogenesis. For example, ommatidial, bristle, and wing formation, which are known also to depend on cell interactions, are affected by neurogenic mutations (Morgan et al. 1925; Welshons 1956, 1965; Shellenbarger and Mohler 1978; Technau and Campos-Ortega 1986; Tomlinson and Ready 1987;
Preiss et al. 1988; Cagan and Ready 1989). Because of the pleiotropic nature of these loci, it is expected that other genes, not necessarily involved in neurogenesis per se, will be found to interact with these genes.

In our efforts to identify the entire repertoire of molecules that can participate in the intercellular processes involving Notch, we have been studying genetic units capable of interacting with the Notch locus (e.g., Xu et al. 1990). In this paper we present one such locus, Serrate, which displays a striking phenotypic interaction with a specific Notch allele known to affect postembryonic development. We demonstrate that Serrate locus encodes an essential function, the loss of which results in embryonic lethality brought about by the disruption of both neuronal and epidermal tissues. Our molecular characterization of Serrate reveals that it encodes an EGF-like transmembrane protein with an overall structural similarity to that of the Notch and Delta gene products. We suggest that like Notch and Delta, Serrate is likely to represent an element in a network of interacting molecules operating at the cell surface during the differentiation of certain tissues.

Results

Serrate and Notch genes interact phenotypically

In the course of genetic crosses designed to detect inter- 
actions between the Notch locus and other genes in Drosophila, a dramatic phenotypic interaction was observed between the Notch allele notchoid (nd) and the third chromosome mutation Serrate /designated $\mathrm{Ser}^{\mathrm{D}}$ in this paper|. The recessive nd mutation, which is associated with an amino acid substitution in the intracellular portion of the Notch protein (Xu et al. 1990), causes wing notches in the adult (see Fig. 1b; cf. to wild type, Fig. la). The $\operatorname{Ser}^{D}$ mutation is dominant and in heterozygous condition produces an adult wing blade very similar to that of $n d$ animals (cf. Fig. $1 \mathrm{~b}$ and c). The phenotypic interaction seen in $n d / Y ; \operatorname{Ser}^{D /}+$ males is characterized by loss of anterior and posterior wing margins, as well as loss of distal wing blade tissue. Concomitant with this loss, thickening of the L3 and L5 wing veins is observed (see Fig. 1d).

Even though both the $\operatorname{Ser}^{D}$ and $n d$ mutations affect wing blade development, the interaction appears to be synergistic because a novel phenotype is seen, that is, rather than just additive effects. To explore this question of synergy further, we constructed flies carrying genetic duplications of $\mathrm{Notch}^{+}$. Animals carrying an extra copy of $\mathrm{Notch}^{+}$normally exhibit a Confluens phenotype characterized by wing vein thickening. Surprisingly, animals bearing $\mathrm{Ser}^{D}$ and an extra copy of $\mathrm{Notch}^{+}$have essentially wild-type wings (Fig. le), that is, both the $\operatorname{Ser}^{D}$ wing nicking and the Confluens phenotypes are suppressed in this combination. This interaction was noted using both $D p(1 ; 2) 51 b$ (a large genetic duplication of 3C1-2; 3D6 including $\left.N^{+}\right)$and CosP479BE $\left[\left(N^{+}\right)\right.$(86E56), a cosmid construct containing only the $\mathrm{N}^{+}$gene [Ramos et al. 1989)].

Because the $\operatorname{Ser}^{D}$ mutation is neomorphic, the interactions observed between $\operatorname{Ser}^{D}$ and Notch mutations might not be representative of interactions normally oc- curring between these gene products. We therefore examined the phenotypes of $n d$ males heterozygous for

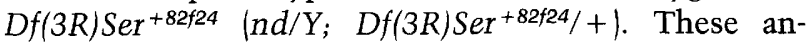
imals exhibit a significantly increased mutant wing phenotype as compared to nd alone (not shown). Thus, it appears that Notch and $\operatorname{Ser}^{D}$ mutually influence each other's phenotypic expression.

\section{Genetic characterization of Serrate}

Previous genetic characterizations have demonstrated that the $\operatorname{Ser}^{D}$ mutation maps to the $97 \mathrm{~F}$ region of the polytene chromosomes and is neomorphic, producing the dominant wing nicking phenotype shown in Figure 1d (Belt 1971; P. Lewis, Yale University, unpubl.). The neomorphic nature is demonstrated genetically via the insensitivity of the $\operatorname{Ser}^{D}$ phenotype to the number of wild-type $\left(\mathrm{Ser}^{+}\right)$copies present, that is, $\mathrm{Ser}^{D} /+/+$ displays a phenotype similar to $\operatorname{Ser}^{D} /+$ and to $\operatorname{Ser}^{D} /$ Deficiency (P. Lewis, pers. comm.). Flies with only one copy of wild-type $\mathrm{Ser}^{+}$(i.e., individuals heterozygous for a wild-type allele over deficiencies) are phenotypically wild type, demonstrating that reduction of gene product (i.e., haploinsufficiency) is not causing the dominant phenotype. Finally, when the $\mathrm{Ser}^{D}$ mutation is homozygous, viable adults are produced that display a more severe wing phenotype than heterozygous $\mathrm{Ser}^{\mathrm{D} /}+$ animals (Fig. 1f). Thus, the expression of the $\operatorname{Ser}^{D}$ wing phenotype appears to be directly related to the expression of a mutant or novel gene product rather than to $\mathrm{Ser}^{+}$gene dosage.

In an effort to obtain amorphic alleles of Serrate, we used X-ray mutagenesis to produce phenotypic revertants of the dominant mutation (for details, see Materials and methods). All five of the revertants of the $\mathrm{Ser}^{D}$
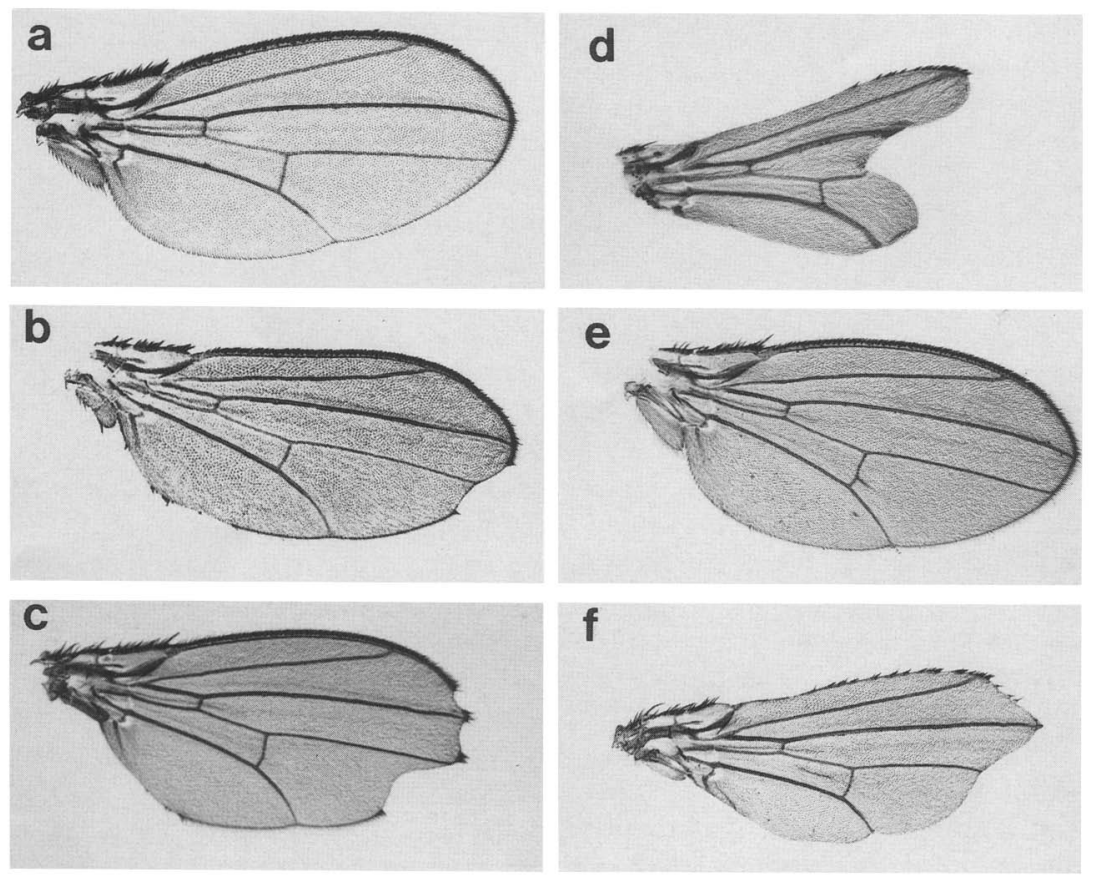

Figure 1. Phenotypic interactions between Notch and Serrate. (a) $w^{a} s p l$ wing blade showing characteristic wild-type symmetry, venation, and marginal wing bristles and hairs. (b) $n d / Y$ male. Distal wing notches and loss of posterior hairs are evident. (c) $\mathrm{Ser}^{D} /+$ heterozygote. Note similarity to $n d / Y$ wing blade in b. (d) $n d / Y ; S^{D} /+$ transheterozygote wing blade. Mutant wing shows typical "fig leaf" shape, distorted wing veins, and loss of the majority of marginal bristles and hairs, with the exception of the anterodistal wing margin. $|e|$ $+/ Y ; \operatorname{Ser}^{D} / D p(3 R) \operatorname{Cos} P 479 B E\left(N^{+}\right)$male. The extra $N^{+}$copy suppresses the heterozygous $\mathrm{Ser}^{D}$ dominant phenotype (cf. to $c$ ). Also note suppression of the Confluens phenotype (see text). (f) $\mathrm{Ser}^{D} / \mathrm{Ser}^{D}$ homozygote. Note the increased severity of the phenotype relative to $\mathrm{Ser}^{D} /+(\mathrm{cf}$. to $\mathrm{C})$. 
mutation are lethal when homozygous and, consistent with the deficiency phenotypes, are phenotypically wild type when heterozygous with a wild-type chromosome. Complementation tests revealed that the Ser ${ }^{\text {revertants }}$ are allelic. Moreover, transheterozygotes of nd with two different Ser revertant alleles (nd/Y; Ser ${ }^{\text {rev2-3 } /+}$ and $n d / Y$; Ser ${ }^{r e v 2-11} /+\mid$ exhibit an enhanced mutant wing phenotype as compared to nd mutants, in agreement with the Ser ${ }^{D}-$ Notch interactions noted previously.

These complementation tests were extended to include another dominant mutation, Beaded of Goldschmidt $\left(B d^{G}\right)$, which also maps to the $97 \mathrm{~F}$ region. Heterozygous adults bearing the $B d^{G}$ mutation display a wing nicking phenotype that is more severe than that observed in $\operatorname{Ser}^{D}$ heterozygotes (data not shown). Moreover, the $B d^{G}$ mutation, unlike $\operatorname{Ser}^{D}$, is homozygous lethal. Finally, three alleles $\left(B d^{43.5}, B d^{862.5}\right.$, and $\left.p 1^{11}\right)$ of a lethal complementation group isolated in K. Anderson's laboratory were shown to be allelic to $B d^{G}$ (P. Hecht, unpubl.; a complete listing of the alleles used and their descriptions is provided in Materials and methods). Although transheterozygotes of $\operatorname{Ser}^{D}$ and $B d^{G}$ are viable, it is interesting to note that $D f(3 R) \mathrm{Ser}^{+82 f 24}$ and most of the Serevertants fail to complement the $B d^{G}$ mutation for viability. The exception is the $\operatorname{Ser}^{\text {rev2-3 }}$ allele, which although homozygous lethal, complements $B d^{G}$. Despite the exceptional Ser rev2-3 allele, these results suggest that the Serrate and $B d$ mutations are alleles of the same gene (see also below). Consistent with this idea is the fact that Serrevertant and $B d$ alleles have similar phenotypes (see also below).

\section{Phenotypic characterization of Serrate lethal alleles}

All of the Serrevertants, as well as the $B d$ alleles we tested $\left(B d^{G}, B d^{43.5}\right.$, and $\left.B d^{862.5}\right)$ and the $D f(3 R) S_{e r}+82 f 24$, exhibit embryonic lethality. Cuticle preparations of unhatched embyros from heterozygous parents revealed a continuous and complex range of phenotypes: The progeny of a single allele from a single brood included individuals that were nearly wild type in appearance, as well as those lacking the majority of differentiated cuticle. Another commonly observed defect was the failure of germ-band retraction. Although all of the alleles displayed the full range of mutant phenotypes (including $\left.D f(3 R) S^{+}{ }^{+82 f 24}\right)$, the proportions of weak or strong phenotypes observed for each individual allele differed. Moreover, three alleles, Serrev2-3, Ser ${ }^{\text {rev2-11 }}$, and Ser ${ }^{\text {rev5-5, in }}$ heterozygous combination with $D f(3 R) \mathrm{Ser}^{+82 f 24}$, revealed the same range of mutant phenotypes as when homozygous.

Embryos exhibiting weak mutant phenotypes often appear to have completely differentiated cuticular structures yet fail to retract the germ band. These embryos appear "J"-shaped within the egg, with the Filzkörper residing at $\sim 50 \%$ egg length on the dorsal surface of the embryo (Fig. 2b). Other weakly affected individuals undergo normal germ-band retraction, have faintly pigmented denticle bands and dorsal hairs, and may have "holes" in the cuticle along the length of the embryo. More severe phenotypes are exemplified by embryos

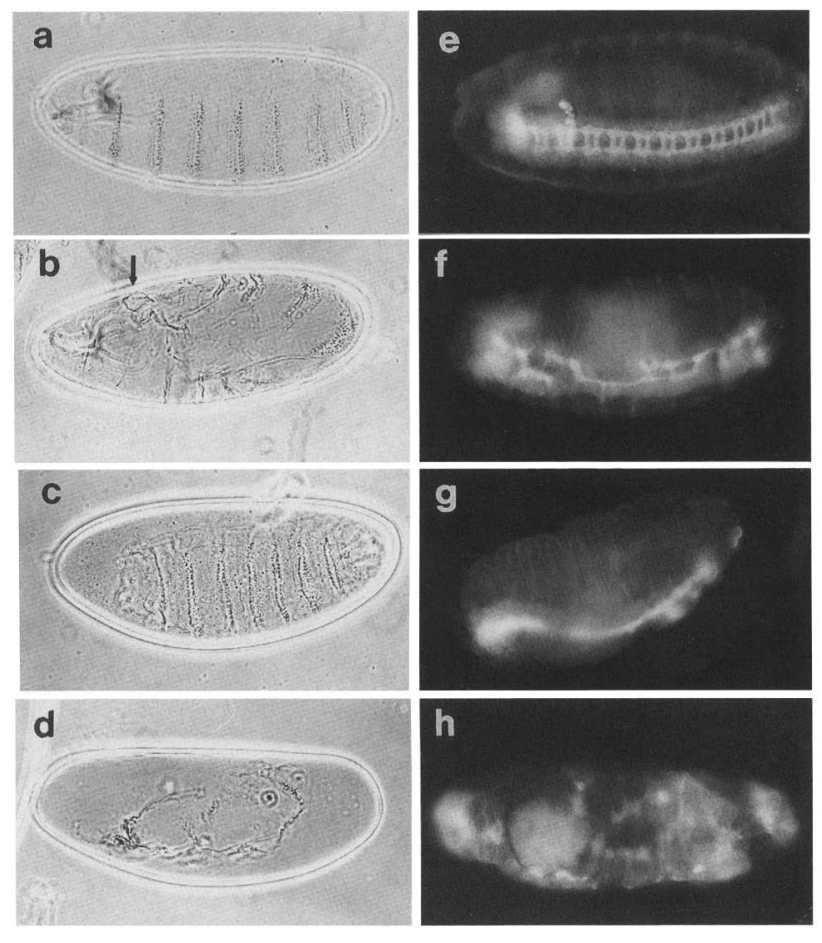

Figure 2. Phenotypes of Serrate lethal mutations. $(a-d)$ Cuticular preparations; $(e-h)$ anti-HRP preparations. (a) Wild-type cuticular pattern of embryo just prior to hatching. (b) Typical nonretracted germ-band Ser revertant homozygote. Note position of Filzkörper $(\rightarrow)$. (c) Ser revertant homozygote lacking the cuticle of the cephalic regions and the first and second thoracic segments. (d) Severely affected Ser revertant homozygote displaying limited cuticle differentiation. (e) Wild-type embryo showing typical nervous system differentiation. (f) Homozygous Ser revertant embryo displaying a "mild" disruption of the longitudinal and commissural axon tracts. $(g) \mathrm{Ser}^{\text {revertant }}$ homozygote; note singular, twisted longitudinal connective. $(h)$ Severely affected Ser revertant homozygote with dispersed clumps of neural material remaining.

with retracted germ bands that lack the cuticle of the entire cephalic regions and sometimes the first and second thoracic segments (Fig. 2c). Other embryos fail to retract the germ band and lack head and thoracic structure, may exhibit twisted germ bands, and/or frequently lack large patches of dorsal or ventral cuticle. Finally, in very severely affected mutant embryos, only a small cuticular patch remains (Fig. 2d). Unlike embryos from a neurogenic mutant, the cuticle that remains in $\operatorname{Ser}^{D} \mathrm{mu}-$ tant embryos can be of dorsal or ventral origin.

We examined the nervous system of mutant embryos using anti-horseradish peroxidase (anti-HRP) antibody (Jan and Jan 1982). Consistent with the cuticular abnormalities, a corresponding range of defects was observed for homozygous individuals of a given Serrevertant allele. Many individuals exhibited missing commissures or breaks in the longitudinal connectives that run between segmental ganglia (Fig. 2f). In other embryos this disruption was more pronounced such that there appeared to be only one longitudinal connective running most of the 
length of the embryo; this condition often correlated with improper germ-band retraction or twisted germ bands (Fig. 2g). Finally, in the most severely affected individuals, only small clumps of anti-HRP staining "neural" material were present throughout the embryo (Fig. 2h). In no case did we see hypertrophy of the central nervous system.

\section{Molecular characterization of Serrate DNA}

In an effort to elucidate the molecular nature of the Serrate gene product, DNA from the $97 \mathrm{~F}$ region was cloned and characterized. A Drosophila genomic clone, previously isolated on the basis of cross-hybridization to the EGF-like domain of the Notch gene (Rothberg et al. 1988), was used as an entry point to initiate a chromosomal walk. From this initial clone, eight recombinant phage spanning $\sim 85 \mathrm{~kb}$ of genomic DNA were isolated (see Fig. 3). A BamHI site adjacent to the region of EGF homology was arbitrarily chosen as coordinate position zero.

Genomic Southern blots containing mutant and wildtype DNAs were probed with DNA from the individual phage isolates to detect and localize rearrangement breakpoints that might be associated with the various Serrate alleles. Within the first phage isolate, $\phi 10.2$, restriction fragment polymorphisms were detected on the original $\mathrm{Ser}^{D}$ chromosome. The polymorphism detected with each of three restriction enzymes (EcoRI, BamHI, and HindIII) was consistent with an insertion of $\sim 5.5 \mathrm{~kb}$ of DNA between map coordinates 0 and -3 (Fig. 3). Subsequent Southern analysis using DNA cloned from $\operatorname{Ser}^{D}$ (data not shown) revealed a repeated DNA sequence, suggesting the presence of a mobile insertional element associated with the mutation. In addition to the insertion, the HindIII site at coordinate -2 has been eliminated in the $\operatorname{Ser}^{D}$ chromosome. Because the parental chromosome from which the $\operatorname{Ser}^{D}$ mutation arose is unavailable, we cannot be certain that the noted polymorphisms are causal to the $\mathrm{Ser}^{D}$ phenotype.

Of the five Ser ${ }^{\text {revertant }}$ alleles, three $\mid$ Ser $^{\text {rev2.3 }}$, Ser ${ }^{\text {rev5-5, }}$, and Ser ${ }^{\text {rev6-1) }}$ appeared cytologically normal and did not exhibit DNA polymorphisms detectable by our Southern analyses. The remaining two revertants, Ser ${ }^{\text {rev2-11 }}$ and Serrev3, had polymorphic DNA restriction fragments within the cloned region. Serev2-11 is an inversion of polytene bands $97 \mathrm{~F}$ to $98 \mathrm{C}$. The $97 \mathrm{~F}$ breakpoint was localized between coordinates +1.5 and +4 , within the region of strongest detectable EGF homology (Fig. 3). $\mathrm{Ser}^{\text {rev3 }}$ is a reciprocal translocation of chromosomes $3 \mathrm{R}$ and $2 \mathrm{R}$, with the $97 \mathrm{~F}$ breakpoint localized between coordinates +15 and +17 (Fig. 3). In situ hybridization of the cloned wild-type genomic DNAs to polytene chromosomes of Ser ${ }^{\text {rev3 }}$ and Serev2-11 confirmed that the observed DNA polymorphisms represent the 97F breakpoints of these chromosomal rearrangements (data not shown).

As noted earlier, Serevertant alleles fail to complement $B d^{G}$, suggesting that the Serrate and $B d$ mutations are alleles of the same gene. As with the $\operatorname{Ser}^{D}$ mutation, the parental chromosome for the $B d^{G}$ mutation was not available; hence, unambiguous assignment of mutant phenotypes to DNA polymorphisms cannot be made. Cytological obvservations of the $B d^{G}$ chromosome failed to reveal any visible abnormalities; however, two regions of DNA polymorphism were detectable by Southern analysis. These regions lie between coordinates 0 to +1 and +14 to +17 . Investigations of the polymorphism at position 0 to +1 were pursued by cloning the mutant DNA sequences. Preliminary results

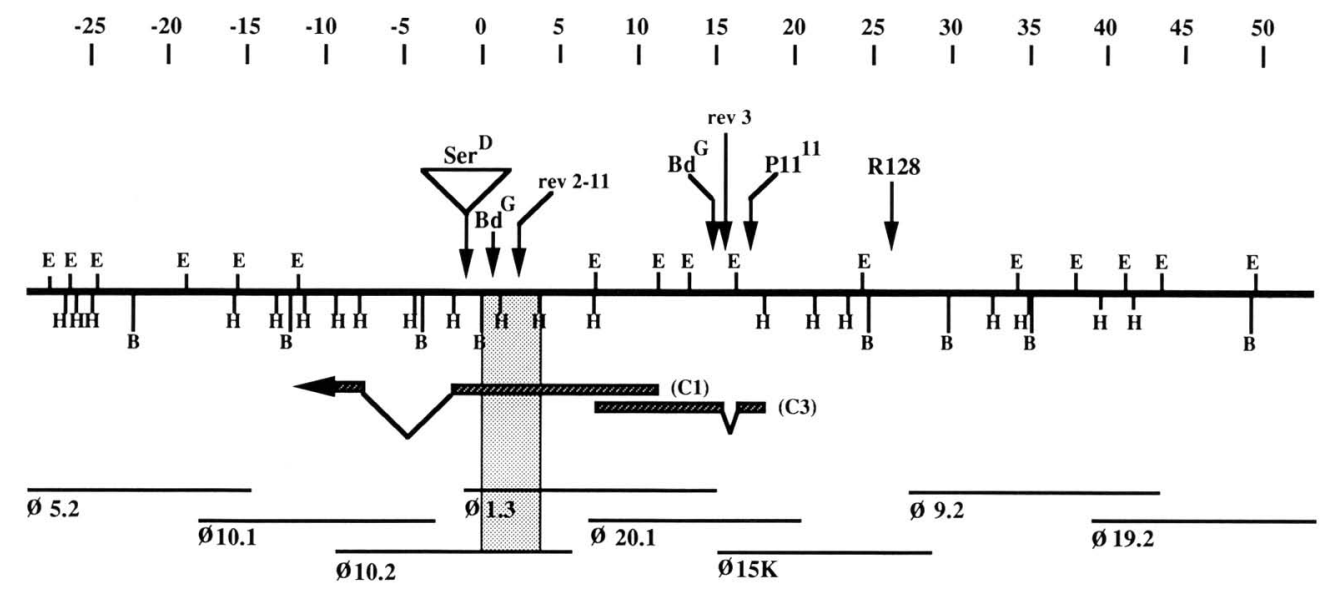

Figure 3. Molecular map of the Serrate-encoding region. Approximately $85 \mathrm{~kb}$ of cloned genomic DNA from the $97 \mathrm{~F}$ chromosomal region are presented along with the restriction sites of three enzymes [(B) BamHI; (E) EcoRI; $(\mathrm{H})$ HindIII]. The locations of individual DNA alterations associated with Serrate allelic breakpoints are displayed above the genomic DNA (for descriptions of mutant alleles, see text and Materials and methods); (rev 3 and rev 2-11) Serrev3 and Ser rev2-11, respectively; (R128) T(Y:3)R128. The shaded box from coordinates 0 to +3 represents the region of EGF homology detectable by Southern hybridization. The BamHI site adjacent to the EGF homology was arbitrarily chosen as position 0 . Map orientation is with the centromere to the left. (Bottom) Individual recombinant phage isolates. The $\mathrm{Cl}$ and $\mathrm{C} 3 \mathrm{cDNAs}$ together constitute the larger of the two Serrate messages $(\sim 5.6 \mathrm{~kb})$. Intron positions and coding capacities have been approximated solely upon cross-hybridization of the cDNAs with the genomic DNA regions. 
indicate that the polymorphisms do not result from a small inversion between these two regions but, rather, from a more complex event.

Of the three mutant chromosomes, $B d^{43.5}, B d^{862.5}$, and pll11, only pll11 was found to have a DNA polymorphism, which was localized between coordinates +17 and +19 (Fig. 3). Genetic and cytological data for the pll ${ }^{11}$ mutation suggest the presence of a very small chromosomal aberration within the $97 \mathrm{~F}$ region (P. Hecht, pers. comm.), and the molecular data are consistent with this observation. Finally, $T(Y: 3) R 128$ is a reciprocal translocation that also breaks within the $97 \mathrm{~F}$ region (Lindsley et al. 1972) and fails to complement $B d^{G}(\mathrm{P}$. Hecht, pers. comm.). The DNA breakpoint for this translocation resides at map coordinates +25 to +28 (Fig. 3). Taken together, these findings strengthen the genetic evidence that Serrate and $B d$ mutations are alleles of the same gene. In summary, of 11 tested chromosomes containing Serrate or Bd mutation, 6 were shown to have associated DNA rearrangements within a $30-\mathrm{kb}$ region known to contain EGF homologous sequences.

To examine the structure of the Serrate transcription unit, we probed Northern blots containing 2- to 14-hr embryonic poly $(\mathrm{A})^{+}$RNA with the recombinant phages spanning this region $\left(\phi 10.1, \phi 1.3\right.$, and $\phi 15 \mathrm{~K}_{;}$Fig. 3$)$. This analysis revealed the presence of two transcripts of $\sim 5.5$ and $5.6 \mathrm{~kb}$ (data not shown). We isolated two overlapping cDNA clones, denoted $\mathrm{Cl}$ and $\mathrm{C} 3$, from an early pupal library (see Materials and methods). Sequence analysis of these cDNAs revealed a perfect overlap of $109 \mathrm{bp}$ for a combined length of $5.6 \mathrm{~kb}$, which is in excellent agreement with the larger of the two transcripts as determined by Northern analysis. Genomic probes unique to the $5^{\prime}$ end of $\mathrm{C} 3$ only detect the larger $5.6-\mathrm{kb}$ transcript. Thus, the size difference between the 5.5 - and $5.6-\mathrm{kb}$ transcripts may represent an alteration in the potential protein-coding capacity or an alteration of $5^{\prime}$-untranslated sequence. The composite $5.6-\mathrm{kb}$ cDNA confirms that the Serrate transcription unit spans $\sim 30 \mathrm{~kb}$ of genomic DNA, encompasses the EGF homologous region, and is interrupted by at least five of the six DNA rearrangements that affect Serrate function (Fig. 3). From Southern analysis, at least two introns are apparent; additional introns are likely but not detectable at this level of resolution.

Serrate encodes a putative transmembrane protein with 14 EGF-like repeats

The complete nucleotide sequence compiled from the cDNAs Cl and C3 is $5561 \mathrm{bp}$ (see Fig. 4) and agrees with the transcript sizes determined by Northern analysis. Within this sequence there is a single large open reading frame (ORF) of $4329 \mathrm{bp}$. There are two possible initiator AUG codons at positions 433 and 442 . Of these, the second AUG is within a sequence context that agrees with the Drosophila consensus sequence determined for translation initiation (CAAAAUG; Cavener 1987). Predicted codon usage within this ORF is highly consistent with established Drosophila melanogaster codon preferences (Beachy et al. 1985). Assuming that translation starts at the second AUG, the Serrate mRNA contains an untranslated leader sequence of at least $441 \mathrm{bp}$, encodes an expected protein product of 1404 amino acids, and terminates with 908 bp of untranslated $3^{\prime}$ sequence (Fig. 5a). However, if translation begins at the first AUG, the protein product is 1443 amino acids.

Hydropathy plots reveal three major hydrophobic regions (Fig. 5b; see also Materials and methods). The first, beginning at amino acid 51 , is likely to represent a signal peptide sequence; a potential signal cleavage site occurs at amino acid 80. A second hydrophobic domain runs from amino acid 540 to 560 . This region does not have a requisite transmembrane structure and is more likely to be a membrane-associated domain. The third hydrophobic domain (amino acids 1220-1245) is bounded by hydrophilic residues and is therefore likely to represent a true transmembrane domain.

The most striking structural feature of the predicted protein is the series of EGF-like repeats (see Fig. 5c). There are 14 copies of this motif, with an additional partial or degenerate repeat occurring toward the amino terminus (see below). In addition, at least three of these repeats are interrupted by stretches of amino acids. The first interruption (labeled A in Fig. $5 \mathrm{c}$ ), which occurs in the fourth complete EGF-like repeat (repeats are numbered beginning from the amino terminus), is $\sim 64$ amino acids in length and is enriched for serine residues. The second interruption (labeled B in Fig. 5c), occurring in the sixth repeat, is $\sim 44$ amino acids long and has numerous hydrophobic residues. This region represents the putative membrane-associated domain noted earlier. The final interruption (labeled $\mathrm{C}$ in Fig. 5c), which occurs in the tenth repeat and is 29 amino acids in length, has an unusual run of threonines $\left[\mathrm{Thr}_{(9)} \mathrm{Ala}\right.$ $\left.\operatorname{Thr}_{(3)}\right]$.

Within the amino-terminal region of the Serrate protein, considerable structural homology (darkly shaded region in Fig. 5c) is observed with the main protein product of the Delta locus (Vässin et al. 1987; Kopczynski et al. 1988). Near the signal peptides for both of these molecules lies a stretch of $\sim 210$ conserved amino acids. Within the first 165 amino acids, there is $\sim 32 \%$ identity, which increases to $>50 \%$ for the remaining 45 amino acids. The latter region corresponds to the partial EGF-like repeat (designated PR in Fig. 5c), which lacks a cysteine residue but retains the other characteristic cysteines and conserved amino acids typically found in the remaining EGF-like repeats. Furthermore, the homology between Serrate and Delta extends beyond these aminoterminal regions since both of these proteins contain EGF-like repeats.

In addition to the extracellular EGF-like sequences, the predicted Serrate protein contains a small intracellular domain of $\sim 160$ amino acids. The internal domain does not contain any significant known structural homologies, although there are numerous potential sites for phosphorylation. (Those identified in the putative intracellular region by the SITES program were at amino acid positions 1283, 1292, 1297, 1349, 1365, 1371, 1389, and 1390.) 
Downloaded from genesdev.cshlp.org on April 26, 2023 - Published by Cold Spring Harbor Laboratory Press

Serrate, an essential EGF-like gene

1 CCGAGTCGAGCGCCGTGCTTCGAGCGGTGATGAGCCCCTITTCTGTCAACGCTAAAGATCTACAAAACATCAGCGCCTATCAAGTGGAAGTGTCAAGTGTGAACAAAACAAAAACGAGAG 121 AAGCACATACTAAGGTCCATATAAATAATAAATAATAATTGTGIGTGATAACAACATTATCCAAACAAAACCAAACAAAACGAAGGCAAAGTGGAGAAAATGATACAGCATCCAGAGTAC

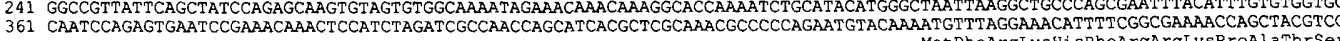

481 TCGTCGTTGGAGTCAACAATAGAATCAGCAGACAGCCTGGGATTGTCCAAGAAGACGGCGACAAAAAGGCAGCGTCCGAGGCATCGGGTACCCAAAATCGCGACCCTGCCATCGACGATC

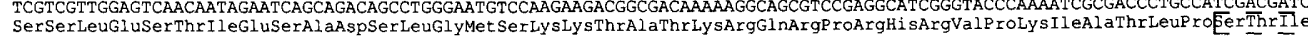

601 CGCGATTGTCGATCATAAAAGTCTGCCTGCAACTTAATTGCTMTAATTTTAATACTGTTAGTCCATAAGATATCCGCAGCTGGTAACTTCGAGCTGGAAATATTAGAAATCTCAAATACC 21 aACAGCCATCTACTCAACGgCTATTGCTGGGGCATGCCAGCGGAACTTAGGGCCACCAAGACGATAGGCTGCTCGCCATGCACGACGGCATTCCGGCTGTGCCTGAagGaGTACCAGACD

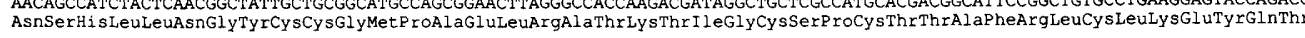

841 ACGGAGCAGGGTGCCAGCATATCCACGGGCTGTTCGTTTGGCAACGCCACCACCAAGATACTGGGTGGCTCCAGCTTTGTGCTCAGCGATCCGGGTGTGGGAGCCATTGTGCTGCCCTTT

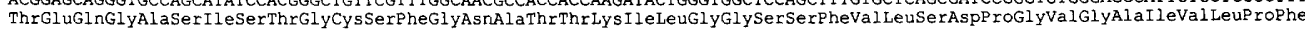

961 ACGTTTCGTTGGACGAAGTCGTTTACGCTGATACTGCAGGCGTTGGATATGTACAACACATCCTATCCAGATGCGGAGAGGTTAATTGAGGAAACATCATACTCGGGCGTGATACTGCCC ThrPheArgTrpThrLysSerPheThrLeuIleLeuGInAlaLeuAspMet TyrASnThrSerTyrProAspAlaGluArgLeuIl eGluGluThrSerTyrSerGl yValI leLeuPro

1081 TCGCCGGAGTGGAAGACGCTGGACCACATCGGGCGGAACGCGCGGATCACCTACCGTGTCCGGGTGCAATGCGCCGTTACCTACTACAACACGACCTGCACGACCTTCTGCCGTCCGCGG SerP roGluTrpLysThrLeuAspHi sIl eGl yArgAsnAlaArg I eThrTyrArgValargValGInCy SAlaValThrTyrTyrAsnThrThrCysThrThrPheCysArgProArg

1201 GACGATCAGTTCGGTCACTACGCCTGCGGCTCCGAGGGTCAGAAGCTCTGCCTGAATGGCTGGCAGGGCGTCAACTGCGAGGAGGCCATATGCAAGGCGGGCTGCGACCCCGTCCACGGC

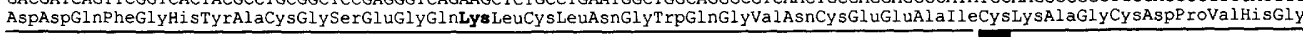

321 AAGTGCGATCGTCCGGGGGAATGCGAATGCAGACCCGGCTGGCGTGGTCCATTGTGCAACGAGTGCATGGTCTATCCCGGCTGCAAGCATGGTTCCTGCAACGGCAGCGCCTGGAAATGC

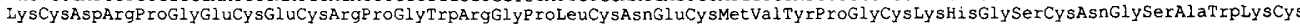

1441 GTGTGCGACACCAACTGGGGTGGCATATTGTGCGATCAAGATTTAAATTTCTGCGGCACCCATGAACCCTGCAAGCACGGCGGCACCTGCGAAAATACCGCTCCGGACAAATATCGGTGC

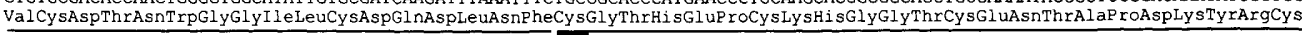

1561 ACATGCGCCGAGGGCCTCTCGGGCGAGCAGTGCGAGATCGTGGAGCACCCATGTGCCACCAGGCCATGCCGCAACGGCGGCACATGCACACTCAAGACGAGTAACCGAACTCAAGCCCAA

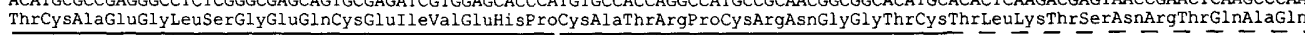

1681 GTGTATCGCACATCACATGGCAGGAGCAACATGGGCCGGCCGGTAAGACGCAGCAGTTCGATGCGCAGCCTGGATCACCTGCGGCCGGAGGGGCAGGCGCTGAATGGCAGCAGCTCCTCG

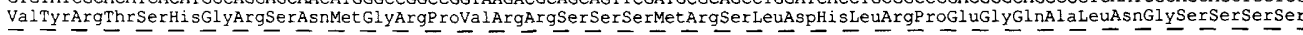

1801 GGATTGGTGTCCCTAGGTTCGCTGCAGCTGCAGCAGCAACTGGCCCCCGACTTCACTTGCGACTGCGCAGCCGGATGGACGGGACCGACATGCGAAATAAATATCGACGAGTGCGCCGGC

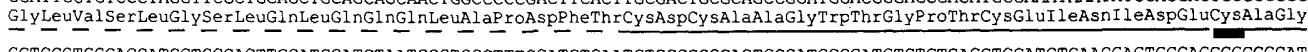
1921 GGTCCCTGCGAGCATGGTGGCACTTGCATCGATCTAATCGGTGGCTTTCGATGTGAATGTCCGCCGGAGTGGCATGGCGATGTCTGTCAGGTGGATGTGAACGAGTGCGAGGCGCCGCAT

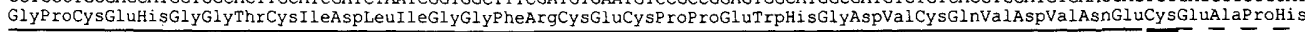

2041 TCCGCCGGAATCGCTGCGAACGCATTGCTGACCACCACAGCCACCGCGATTATTGGTAGTAATCTGAGCAGTACTGCTCTTCTGGCCGCTCTGACCAGTGCAGTGGCATCCACATCCTTO

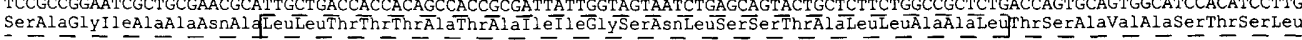

2161 GCCATCGGACCCTGCATCAATGCCAAGGAGTGTCGCAATCAGCCGGGTTCCTTTGCCTGCATCTGCAAGGAGGGCTGGGGCGGAGTGACCTGTGCCGAGAATCTAGATGACTGTGTGGGT

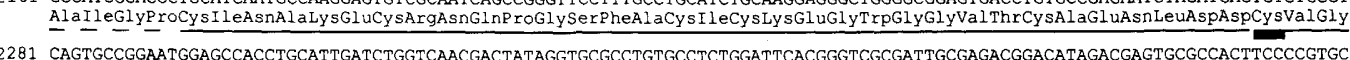

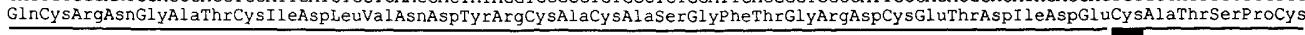

2401 CGAAACGGAGGCGAATGTGTGGACATGGTGGGCAAATTCAATTGCATTTGCCCACTTGGCTACTCGGGTTCTCTGTGCGAGGAGGCCAAGGAGAACTGCACACCGTCGCCATGTTTGGAC

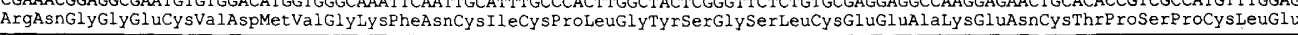

2521 GGTCACTGCCTCAACACGCCCGAAGGATACTACTGCCATTGTCCACCGGATCGCGCCGGAAAGCACTGCGAGCAACTGCGTCCGCTCTGCTCCCAGCCGCCCTGCAACGAGGGCTGCTTC

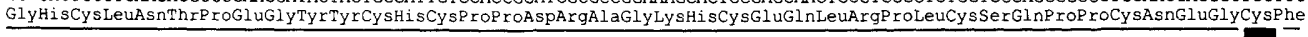

2641 GCCAATGTCAGCCTAGCGACGTCAGCGACAACGACGACGACAACCACCACAACGGCGACAACGACAAGGAAGATGGCCAAGCCAAGCGGATTGCCCTGCAGCGGACACGGCAGCTGCGAG Al aAsnVal SerLeuAl aThrSerAla ThrThrThrThrThrThrThrThrThrAlaThrThrThrArgLy SMetAlaLysProSerG1yLeuProCysSerGlyHi SGlySerCy SGlu

2761 ATGAGCGACGTGGGCACCTTCTGCAAATGCCATGTGGGCCACACCGGCACCTTCTGCGAGCACAATCTCAACGAATGCTCGCCGAATCCTTGTCGAAATGGGGGAATTTGCCTTGACGGC

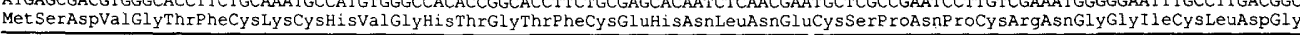

2881 GACGGCGATTTTACATGCGAGTGCATGTCGGGCTGGACAGGTAAACGCTGCTCGGAGCGCGCTACAGGTTGTTATGCCGGTCAGTGCCAGAATGGTGGTACCTGCATGCCTGGAGCCCCC

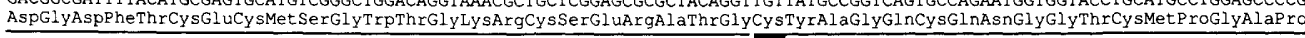

30.01 GACAAGGCTCTGCAGCCGCATTGCCGCTGTGCGCCAGGTTGGACTGGTCTGTTTTGCGCCGAGGCTATT TACCAGTGTCGCGGGCAGCCGTGCCACAATGGCGGAACGTGCGAGTCGGGA

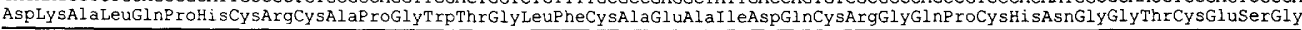

3121 GCGGGCTGGTTCCGCTGCGTCTGCGCTCAGGGATTCTCTGGTCCAGACTGCCGCATCAATGTGAACGAGTGCTCGCCACAGCCTTGCCAGGGCGGTGCCACCTGCATCGACGGAATCGGT AlaGlyTrpPheArgCysValCysAlaGlnGlyPheSerGlyProAspCySArgI leAsnValAsnGluCysSerProGlnProCysGlnGlyGLyAlaThrCysIleAspGIyIleGly

3241. GGATACAGCTGCATCTGCCCACCAGGAAGGCATGGATTGCGGTGTGAAATTTTGCTCTCCGATCCCAAGTCCGCCTGCCAGAACGCAAGCAACACTATCTCTCCGTATACAGCTCTAAAC GlyTyrSerCysI leCysProP roGlyArgH is GlyLeuArgCysGluI leLeuLeuSerAspProLysSerAlaCysGInAsnAlaserAsnThrIleSerProTyrThrAlaLeuAsn

3361 CGAAGCCAAAACTGGCTGGATATTGCTCTAACCGGAAGAACAGAAGACGATGAGAACTGCAATGCGTGTGTCTGCGAAAACGGCACCTCTCGGTGCACGAATCTCTGGTGTGGATTGCCC ArgSerGInAsnTrpLeuAspI leAlaLeuThrGlyArgThrGluAspAspGIuAsnCy SASnAlaCysValCysGluAsnGlyThrSerArgCysThrAsnLeuTrpCysGlyLeuPro

3481 AATTGCTATAAGGTGGATCCGCTCTCCAAGTCCTCGAATCTGTCCGGTGTTTGCAAACAGCACGAGGTGTGCGTTCCGGCACTGAGTGAGACATGCCTGTCATCGCCTTGTAATGTTCGT

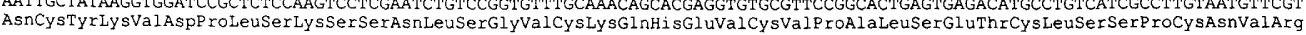

3601 GGAGATTGCCGGGCACTGGAACCATCGCGTCGGGTTGCTCCACCCCGACTGCCAGCCAAATCTAGCTGCTGGCCCAATCAGGCCGTGGTCAACGAGAACTGCGCCCGACTCACCATCCTI GlyAspCy SArgAlaLeuGluP roSerArgArgValAlaP roP roArgLeuProAlaLySSerSerCysTrPProAsnGlnAlaValValAsnGluAsnCySAlaArgLeuThrI leLeu

3721 TTGGCCCTGGAGCGAGTGGGCAAGGGAGCTTCGGTGGAGGGTCTCTGCTCCCTGGTAAGGGTGCTGCTGGCTGCCCAGTTGATCAAGAAGCCGGCGAGTACTTTTGGCCAGGATCCGGGA

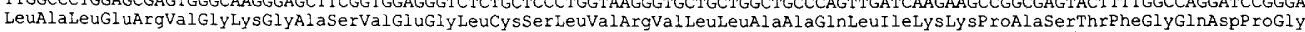

3841 ATGCTTATGGTGCTCTGCGATCTCAAAACGGGCACCAATGATACCGTTGAACTAACTGTGTCGTCCAGTAAATTAAATGATCCCCAGCTGCCAGTGGCGGTGGGTCTGCTGGGTGAACTC Met LeuMetVal LeuCy SAspLeuLysThrGlyThrAsnAspThrValGluLeuThrValSerSerSerLysLeuAsnAspProGlnLeuP rovalAlavalGlyLeuLeuGlyGluLeu

3961 CTGAGCTCCAGGCAGTTGAATGGCATCCAGCGGCGCAAGGAACTGGAGCTGCAGCATGCAAAATTGGCTGCCCTCACCTCCATTGTGGAGGTCAAGTTGGAAACGGCCCGCGTGGCCGAT

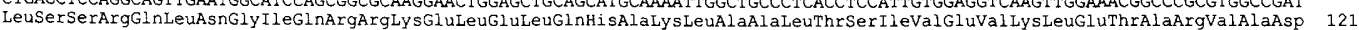

4081 GGATCGGGTCATAGTCTGCTGATAGGAGTGCTATGCGGTGTCT'TTATAGTCCTGGTGGGATTCTCGGTGTTCATCAGTCTTTACTGGAAACAGCGTCTGGCTTATCGCACCAGTTCGGGA

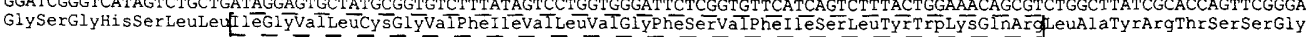

4201 ATGAACTTAACTCCCTCCCTGGATGCACTGCGTCACGAGGAGGAGAAGTCGAATAATCTGCAGAACGAGGAGAATCTGCGAAGGTATACAAATCCGCTGAAGGGCAGCACCAGTTCCCTA MetAsnLeuThrP roSerLeuAspal a LeuArgHi i GluGluGluLysSerAsnAsnLeuGlnAsnGluGluAsnLeuArgArgTyrThrAsnProLeuLysGlySerThrSerSerLeu

321 AGAGCGGCCACCGGCATGGAACTAAGCCTCAATCCCGCTCCGGAATTAGCCGCCTCGGCGGCGAGTAGTTCCGCCTTGCACAGATCGCAGCCACTATTCCCGCCATGCGATTTCGAGCGT ArgAlaAlaThrGlyMetGluLeuSerLeuAsnP roAlaP roGluLeuAlaAlaSerAlaAlaSerSerSerAlaLeuHisArgSerGlnProLeuPheProProCysAspPheGluArg

4441 GAGCTGGACTCCAGTACGGGCCTGAAGCAGGCGCACAAGCGGAGCTCACAGATTCTGCTGCACAAAACCCAAAACTCGGACATGCGGAAGAACACTGTGGGCTCGCTGGACAGTCCGCGT GluLeuAspSerSerThrGlyLeuLysG InAlaHisLysArgSerSerGinI leLeuLeuHisLysThrGlnAsnSerAspMetArgLy SAsnThrValGlySerLeuAspSerProArg

4561 AAGGACTTTGGCAAGCGGTCGATCAACTGCAAGTCCATGCCACCCTCTTCGGGCGACGAGGGCTCCGATGTCCTTGCCACCACTGTGATGGTTTAGCCGTGATCTCACCAACCAACCAAT LysAspPheGlyLySArgSerIleAsnCy LYysSerMetProP roSerSerGlyAspGluGlySerAspVal LeuAlaThrThrValMetVal

4681 CAAGAAACCAACCAGCCGCCCACAGCCAGCTCAAAGTTCCAATTGCCACAGCACGGGCGCTATTTCCAAGTGCATTAGTAGCGTAATTAAAACTAGGATATTGTTAAGGATACCAAGGTA 4801 GGCCACAACGGAGTGGCTCTGTTGAAAACG TAAAGT TCTAAAAATCCAGGTCTCTCAGACAAAGATGAGGTACACAAATTAAATTGGCTAGTTAATCAAGCATGTTATGGCCACGGGATGG

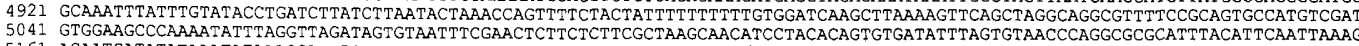
5161 ACAATGATATATAAATATAAACGAAATCAACTCCTTGGCTAGCACAAGCTGTATGTATATAGTTCTCATTTAGGATCGTCGCGCTCTATATTGTGTATAAGCTGTAAATACTGTAAATTA 5281 GCAGTTACCGTTATTGTATTTTGTTCTATAGTTAGATTGGTACTATTAAACTAAGAACCAGCCGCAACGCGTTAGACTTTAAAAGTTGTTTGCAATTGTACGCAATAATATAGTTTTATGC 5401 TCGTAGTTAGGTAGCTGTGTAACCGGGTAAGATTCAAACGATTTTGTACTGTATTATATACCTATCTGTGTAGTAATATTTATTTATTATATTAAATT TGATCTAGACGCAATAAAGTAA

Figure 4. (See following page for legend.) 


\section{Expression of Serrate RNA}

Northern analysis of developmentally staged RNAs revealed that the majority of Serrate expression is represented by two coordinately regulated transcripts of 5.5 and $5.6 \mathrm{~kb}$, which first appear $4-8 \mathrm{hr}$ into embryogenesis (Fig. 6). These transcripts show peak expression between 8 and $12 \mathrm{hr}$ of embryogenesis and diminish thereafter; however, they continue to be readily detectable throughout development except for the adult stages (Fig. 6). In addition to these major transcripts, a smaller $(3.4 \mathrm{~kb})$ transcript is expressed transiently between 2 and $4 \mathrm{hr}$ of embryogenesis (Fig. 6).

We undertook an analysis of the spatial distribution of RNA transcripts from the Serrate locus to identify regions of the embryo that may require Serrate function. Using the whole-mount in situ method (Tautz and Pfeifle 1989) and employing nonradioactive probes that hybridize to both the 5.5- and 5.6-kb transcripts, we found that Serrate mRNA accumulates in a dynamic pattern beginning from mid-embryogenesis (late stage 10) and persisting until the latest stages examined (stage 16); [embryonic stages are those of Campos-Ortega and Hartenstein (1985)]. Because the tissue distribution of the two transcripts may be regulated independently, we note that the observed RNA localizations may represent a composite for both transcripts. We also note the possibility of a low level of Serrate RNA in the yolk of pregastrulation embryos because faint staining of the yolk was observed consistently. Although this staining was never observed with control probes (see Materials and methods), the presence of yolk staining is known to be a common artifact of the whole-mount in situ technique (Ashburner 1989). However, if this observation is not artifactual, the observed staining may correspond to the expression of the transient 3.4-kb RNA species observed by the Northern analysis of this same developmental stage.

Initial cellular localization is seen in late-stage $10 \mathrm{em}$ bryos and consists of a ring of cells in the foregut. The foregut is formed by the invagination of the stomodeum (the initial event of stage 10); thus, the foregut is actually derived from ectodermal tissue. Shortly thereafter, a bilateral patch of expressing cells appears in the anterior-most portion of the head, the presumptive clypeolabrum (Fig. 7a). Additional areas of expression appear abruptly at the end of stage 10 in a group of cells on the lateral edge of abdominal segment 8 , followed by cells near the proctodeum and lateral epidermis of abdominal segment 9 (Fig. $7 b$ ). Later, during stage 11 , expression is detected within cells located at the junction between the labial and maxillary lobes and within cells located near the tracheal pit of the first thoracic segment. The expression pattern progresses to include a group of lateral epidermal cells located between the tracheal pits in each of the thoracic and abdominal segments (Fig. 7c). In addition, each abdominal segment displays a cluster of cells on either side of the ventral midline.

During germ-band retraction (stage 12), the lateral epidermal cell patches broaden to form stripes that lie in the middle of each segment. A portion of these cells appears to coalesce into an internal longitudinal stripe that is coincident with the developing tracheae (see Fig. $7 e-h)$. The cells that remain on the surface extend dorsally and ventrally, forming a zigzag-shaped pattern (Fig. $7 \mathrm{~g}$, arrows). This surface expression in the thoracic segments is wider, more intense, and extends further dorsally and ventrally than in the abdominal segments (Fig. $7 \mathrm{~g}$ ). Later in embryogenesis (stages 14 and 15) the surface epidermal expression, with the exception of the first thoracic segment, diminishes relative to the tracheal expression. Later, intense expression is observed in what appear to be ectodermal invaginations located dorsolaterally on the thoracic segments (Fig. 7i). These pockets of cells may correspond to primordia of imaginal discs; in the first thoracic segment they appear to be closely associated with the opening of the anterior spiracle.

Coincident with the lateral expression, another segmentally reiterated pattern evolves in the ventral epidermis of the trunk. In the extended germ-band embryo, this pattern, which consists of stripes of expressing cells near the anterior border of the abdominal segments, lies out of register with the corresponding lateral expression (Fig. 7c). The pattern in the thorax contrasts with that in the abdomen and consists of only small clusters of expressing cells in the lateroventral region (see Fig. $7 \mathrm{f}, \mathrm{h}$ ). The ventral expression is quite intense through stage 13 and dissipates thereafter (Fig. 7l).

Serrate expression is also observed in the ectodermally derived portions of the gut. The earliest expression is evident in the foregut and persists throughout embryonic development (Fig. 7a). During germ-band retraction, a tightly defined, intensely expressing ring of cells lies at the junction with the anterior midgut. The proventriculus develops from this area; however, expression is limited to the ectodermally derived portion of this composite structure (King 1988). Hindgut expression, though appearing later than foregut expression, occurs at an analogous position, that is, where ectoderm meets endoderm. The initial expression in the hindgut is seen at the

Figure 4. Serrate sequence analysis. The complete 5561-bp sequence derived from cDNAs Cl and C3 (see text) is shown. Nucleotide numbering is at left; amino acid numbering of the predicted ORF is at right. The deduced protein product appears to be a transmembrane protein of 1404 amino acids. Hydrophobic regions are denoted inside dashed boxes; amino acids $51-80$ represent the likely signal peptide; amino acids 542-564 represent the potential membrane-associated region (see text); amino acids $1221-1245$ represent the putative transmembrane domain. The first cysteine of each of the 14 EGF-like repeats is denoted with a solid black box, and each repeat is underlined. The partial EGF-like repeat is considered "degenerate," as the fourth cysteine residue of this repeat has been changed to lysine (shown in boldface type at amino acid position 268). The initial cysteine of this repeat is denoted with an open box (amino acid 284), and the repeat is underlined. Amino acid insertions occur in the fourth, sixth, and tenth EGF-like repeats and are denoted by dashed underlines. 
a

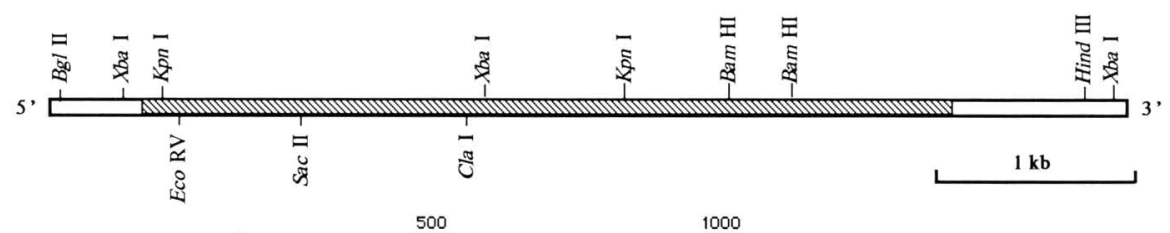

b

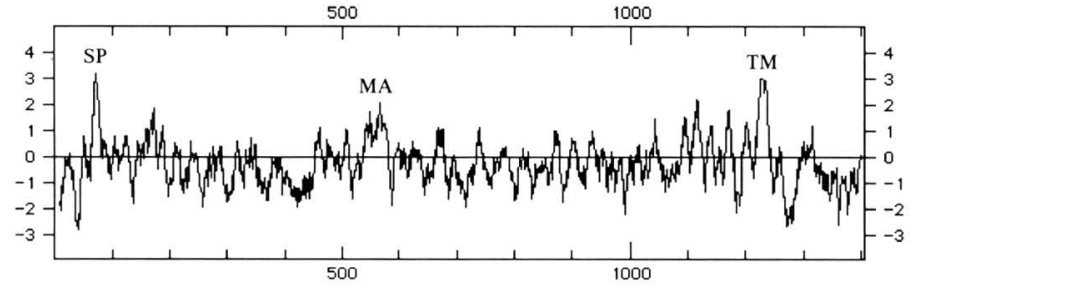

c

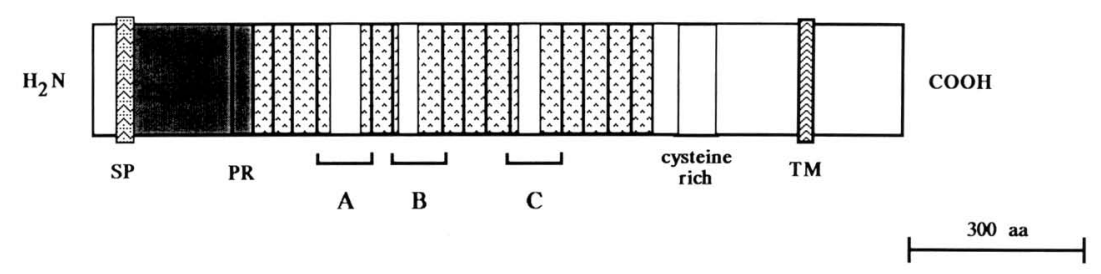

Figure 5. The Serrate transcript and deduced protein product. (a) The composite transcript (shown) was constructed from the Cl and C3 cDNAs, which overlap by 109 bp. Selected restriction enzyme cleavage sites are shown. The hatched box represents the 4212 -bp ORF. Open boxes represent the 442-bp 5'-untranslated leader and 900-bp 3'-trailer sequence. $\mid$ b $\mid$ Kyte-Doolittle hydropathy plot of the deduced 1404-amino-acid protein. (SP) Putative signal peptide; (MA) potential membrane-associated region; (TM) likely transmembrane domain. $(c)$ Cartoon representation of the gross structural features of the predicted Serrate protein. The darkly shaded region, including the partial EGF-like repeat (PR), is $\sim 250$ amino acids in length and homologous to the Delta protein. Bracketed EGF-like repeats $(\mathrm{A}, \mathrm{B}$, and $\mathrm{C})$ contain insertions of amino acids and thus differ from the canonical EGF-like structure (see text). Other features of the protein include the signal peptide (SP), a cysteine-rich region, a transmembrane domain (TM), and an intracellular region of $\sim 160$ amino acids.

time of germ-band retraction (stage 12) as a wide band of cells where the Malphigian tubules are forming, but never includes the tubules themselves. Later still (stage 14), an additional ring of expression appears in the hindgut approximately midway between the insertion point of the Malphigian tubules and the proctodeum (Fig. $7 \mathrm{~h}$ ). Expression at the posterior-most end of the embryo, near the proctodeal opening, initiates early /stage 11; Fig. 7b). This expression within the telson remains at high levels throughout embryonic development, eventually forming a ring of cells around the presumptive anal pads (Fig. 71).

Within the head region, Serrate expression is temporally and spatially dynamic. The earliest expression occurs in the presumptive clypeolabrum (stage 10; Fig. 7a) and becomes broader and more intense as development proceeds. Early expression between the labial and maxillary lobes increases along their borders, and expression is also seen in the anterior of the mandibular lobe during stage 12 (Fig. $7 \mathrm{~d}$,e). In addition, expression is now observed in the hypopharyngeal region, just posterior to the stomodeum, and at the base of the labial lobes in an area encompassing the salivary gland duct opening (Fig. 7d). There is also low-level expression in the dorsal procephalic epidermal region (not shown). By the end of germ-band retraction (stage 13) expression encompasses the entire mandibular lobe. As a consequence of the cellular movements associated with head involution (stages 14-16), the expressing cells of the clypeolabrum, hypopharynx, and labial lobes combine to form the pharynx. Prior expression in the area of the salivary gland placodes is now limited to the ducts of the developing salivary gland (Fig. 7i). The maxillary and mandibular lobes, which have moved to the anterior-most region of the embryo, express intensely at this time (Fig. 7j).

Serrate expression in the central nervous system (CNS) is apparent during stage 12 as a segmentally reiterated array of single cells along the lateral edge of the ventral nerve cord and within the supraesophogeal ganglia (brain hemispheres). By the end of germ-band retraction (stage 13), there are now two cells that appear to express in each hemisegment of the ventral nerve cord (not shown). However, by stage 15, ventral nerve cord expression is again limited to a single cell per hemisegment (Fig. 7i) while expression in the brain hemispheres remains unchanged (Fig. $7 \mathrm{k}$ ).

In summary, there are a wide array of tissues that express Serrate mRNA, and the expression pattern is tightly regulated both temporally and spatially. In addition, it should be stressed that at the present level of resolution, Serrate expression appears to be restricted exclusively to cells of ectodermal origin.

\section{Discussion}

Proteins containing EGF repeats have been shown to play an important role in many aspects of development 


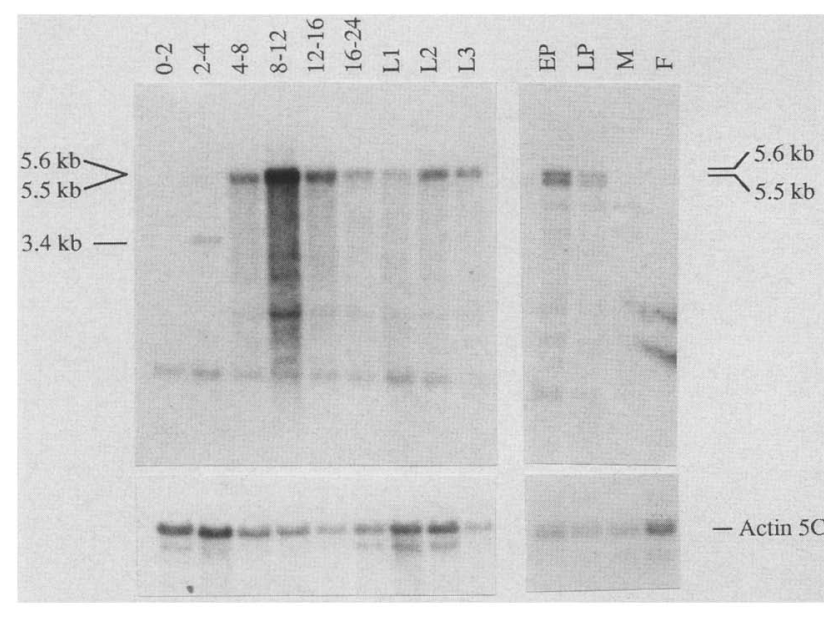

Figure 6. Temporal profile of Serrate transcript accumulation. Each lane contains $5 \mu \mathrm{g}$ of poly $\mid \mathrm{A})^{+}$RNA. The stage of the embyronic RNAs is denoted in hours after egg laying; (L1, L2, and L3) RNA from the first-, second-, and third-larval instar periods; (EP and LP) early and late pupal stages; ( $M$ and F) adult male and female RNAs, respectively. A composite cDNA subclone (constructed from $\mathrm{Cl}$ and $\mathrm{C} 3$ ) was used as a hybridization probe. Serrate transcription is represented primarily as a 5.5- and 5.6$\mathrm{kb}$ doublet beginning at $4-8 \mathrm{hr}$ of embryogenesis. A transient 3.4-kb transcript is observed only during $2-4 \mathrm{hr}$ of embyrogenesis. The pupal and adult RNAs were fractionated on a separate gel for a longer period of time for better resolution. Equivalent loadings of RNA were noted by ethidium bromide staining of the RNA gels and confirmed by subsequent probing with an actin 5C probe (bottom; Fyrberg et al. 1983). Minor bands were not consistenly observed in other blots and may reflect other EGF-homologous transcripts.

in a variety of organisms (Anson et al. 1984; Appella et al. 1987; Rothberg et al. 1988; Yochem et al. 1988). A common feature of these functionally diverse proteins is that they have been implicated in extracellular events and direct protein-protein interactions (e.g., Furie and Furie 1988; Engel 1989; Siegelman et al. 1990|. More recent work in our laboratory (Fehon et al. 1990) has shown that the extracellular domains of Notch and Delta, which carry tandem arrays of EGF-like repeats, are implicated in $\mathrm{Ca}^{2+}$-dependent heterotypic adhesive interactions. Thus, the interactions observed between Notch and Delta at the molecular level are consistent with those that had been noted previously at the genetic level (Vässin et al. 1985; de la Concha et al. 1988; Xu et al. 1990).

The Serrate locus captured our attention by virtue of the synergistic genetic interactions noted between Serrate and the Notch allele nd. Although genetic interactions between two mutations are simply suggestive of underlying molecular interactions, the predicted structure of the Serrate gene product, with its putative transmembrane domain and homology to EGF, provides a reasonable working hypothesis that Notch and Serrate may interact at the protein level.

Unlike Notch and Delta, the 14 EGF repeats of Serrate are not completely contiguous. At least three of these repeats contain sizable interruptions consisting of insertions of long stretches of amino acids. Similarly, interruptions have been noted in 2 of the 30 EGF-like repeats of the Drosophila gene crumbs (Tepass et al. 1990). In Serrate, the interruption that occurs in the sixth repeat is particularly intriguing because it consists largely of hydrophobic amino acids. Although hydropathy plots indicate that this region does not conform to known transmembrane regions, it could represent a membraneassociated domain that serves to "tie" the protein back to the membrane. The interruption in the tenth repeat is also unusual in that it bears a stretch of threonines $\left(\mathrm{Thr}_{(9)}\right.$ Ala $\left.\mathrm{Thr}_{(3)}\right)$. A similar motif of 13 contiguous threonine residues is found in the glycoprotein glutactin, a basement membrane protein of Drosophila (Olson et al. 1990).

Although we do not yet have direct evidence for an involvement of Serrate in cell-cell interactions, the overall structural similarity among Notch, Delta, and Serrate is certainly suggestive of such phenomena. Furthermore, we note that the extracellular homology between the Serrate and Delta proteins extends beyond their EGF-like repeats: A stretch of 210 amino acids is highly conserved near the amino terminus of both proteins. Thus, this leads to the speculation that the Serrate and Notch proteins may interact via their extracellular domains. For instance, it is conceivable that the Serrate and Delta proteins may compete for binding with the Notch protein. Such interplay could underlie the genetic interactions observed between Notch and Serrate. If the observed genetic interactions between Notch and Serrate had been only with the original $\operatorname{Ser}^{D}$ allele, it could have been argued that this neomorphic mutation is allowing two functionally disparate but structurally similar molecules to interact out of their normal contexts. But because we observe genetic interactions with Serrate alleles, it is likely that we are observing a manifestation of normal Serrate-Notch interactions.

We have shown that phenotypic revertants of $\operatorname{Ser}^{D}$ behave genetically in a similar fashion to known deficiencies for the locus, that is, they are homozygous lethal during embryogenesis and completely recessive as heterozygotes. We also gathered evidence indicating that the mutation $B d^{G}$, which was thought to belong to a distinct complementation group, may be an allele of Serrate. The strongest argument in favor of that conclusion came from two observations: On one hand, most Ser revertant alleles fail to produce viable $B d^{G}$ transheterozygotes; on the other, the lethal embryonic phenotypes of Serrate and $B d$ mutations are essentially identical. Complementation of $\operatorname{Ser}^{D}$ and $B d^{G}$ for viability was not entirely unexpected, nor does it necessarily contradict this argument, because the $\operatorname{Ser}^{D}$ allele produces viable animals when heterozygous to a deficiency. In addition, the DNA polymorphisms associated with both the $B d^{G}$ mutation and the Serevertants are located within the same transcription unit. We recognize that additional genetic evidence is needed to formally demonstrate that Serrate and $B d$ belong to the same complementation group.

The embryonic lethal phenotypes of $\operatorname{Ser}^{\text {rev2-3, }} \operatorname{Ser}^{\text {rev2-11, }}$ 

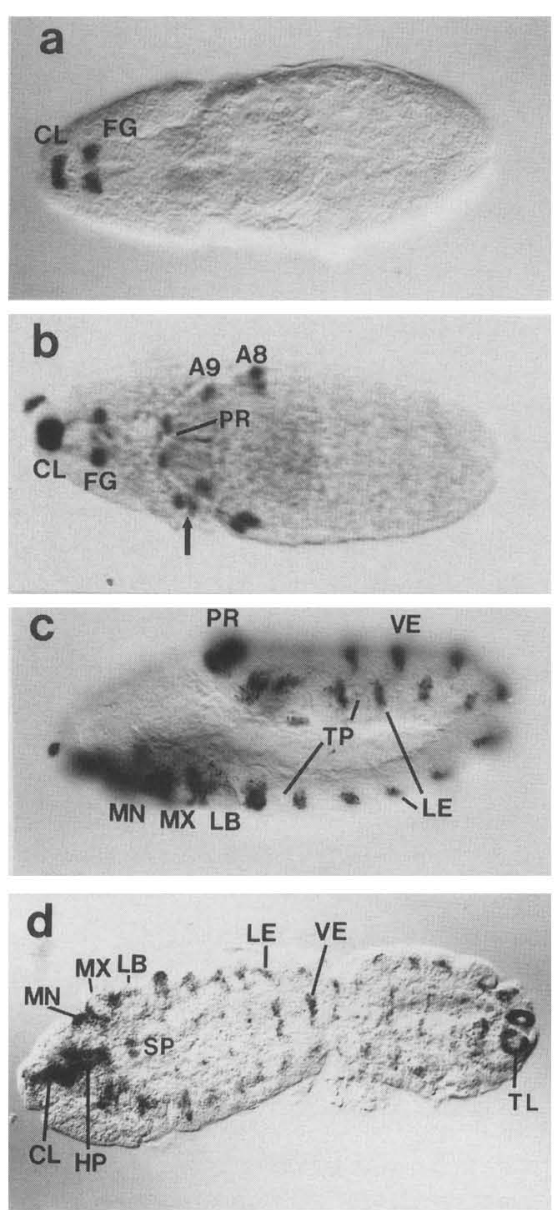
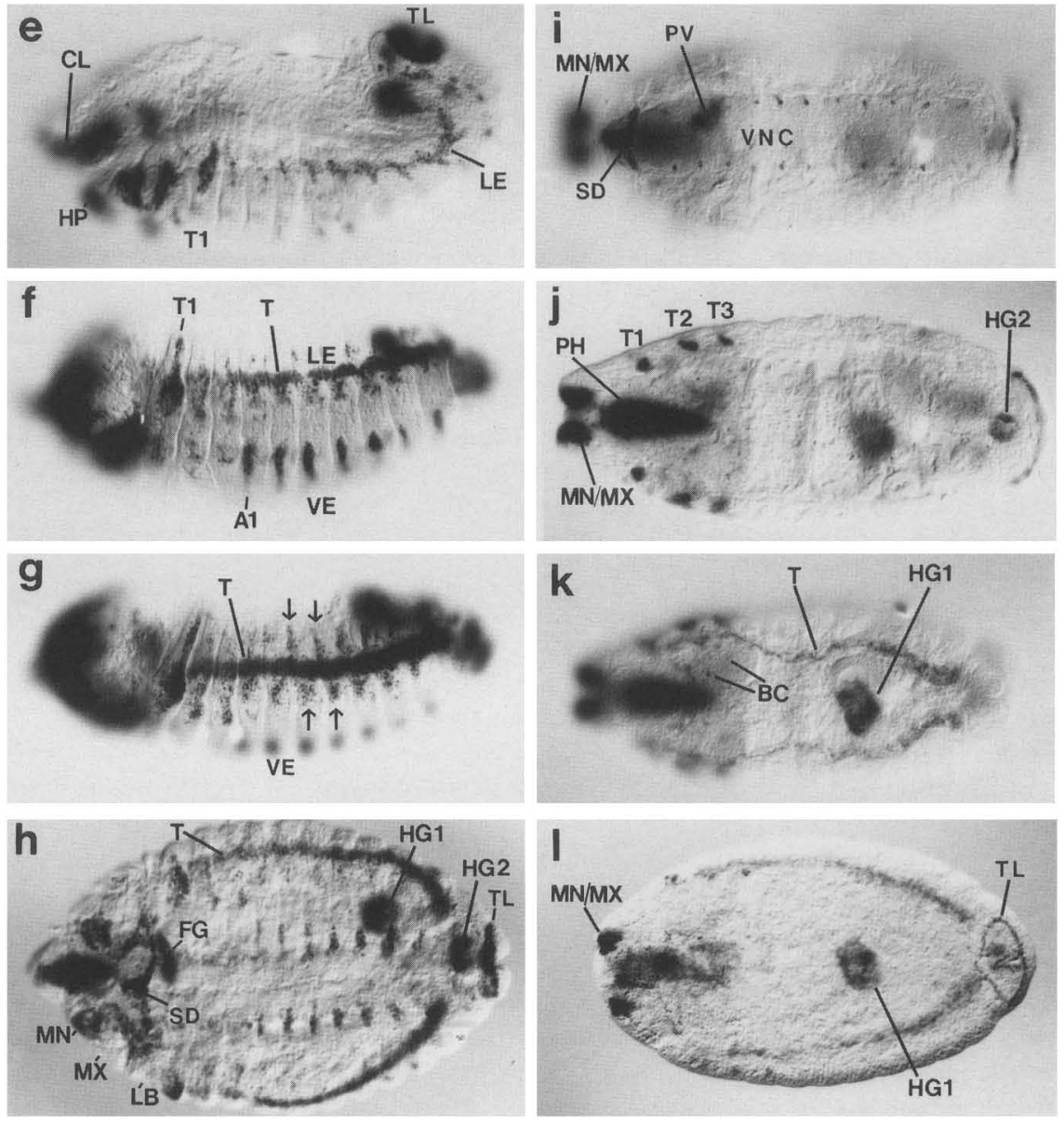

Figure 7. Whole-mount in situ Serrate transcripts. Embryos are oriented with anterior to the left and dorsal side up unless otherwise noted. (a) Dorsal view of an early-stage 10 embryo (mid-dorsal focal plane). Earliest expression occurs in the ectoderm of the foregut (FG) and presumptive clypeolabrum $(\mathrm{CL})$. (b) Dorsal view of a germ-band-extended embryo (late stage 10). Additional expression occurs near the proctodeum (PR), within the eighth (A8) and ninth (A9) abdominal segments, and in the labial and maxillary primordia (arrow). (c) Lateral view of an early-stage 11 embryo. The lateral (LE) and ventral (VE) expression patterns are out of register and do not include the tracheal pits (TP). (d) Germ-band-extended embryo (mid-stage 11) dissected and flattened such that the dorsal surfaces are at the lateral edges. Extensive expression is observed between the labial (LB), maxillary (MX), and mandibular (MN) lobes and within the hypopharynx (HP) and clypeolabrum (CL). Expression is also apparent in the salivary gland placodes (SP) that have moved to the ventral midline. Note relationship between lateral and ventral patterns and elaboration of expression in the tail region [presumptive telson (TL)]. (e) Germ-band-retracting embryo (stage 12; lateral view). Lateral expression (LE) is beginning to coalesce. (f) Lateral view of a germ-band-retracted embryo (stage 13). The lateral expression is beginning to extend both dorsally and ventrally in each thoracic and abdominal segment and is most pronounced in the first thoracic segment (T1). A portion of the lateral expression now appears to include the presumptive trachea (T). Ventrally, note different expression (VE) patterns in the thoracic vs. abdominal segments. $(g)$ Lateral view of an early-stage 14 embryo. Outline of the presumptive trachea $(T)$ is distinct from the overlying epidermal expression. Arrows denote the zigzag pattern of lateral expression. $\{h \mid$ Dissected embryo (stage 14) opened along the dorsal midline and laid flat. Two areas of hindgut expression (HGl and HG2) are apparent; HGl occurs near the origin of the Malpighian tubules. (i) Ventral view of a stage-16 embryo focusing on the ventral nerve cord (VNC). Earlier expression in the salivary gland placodes (SP in $d$ ) now constitutes the SD. Expression in the proventriculus $(\mathrm{PV})$ and the maxillary/mandibular region $(\mathrm{MX} / \mathrm{MN})$ is slightly out of focus. (j) Dorsomedial focal plane of same embryo as in $i$; head involution is nearly complete. The in-pocketings of expression in the thoracic segments (T1, T2, and T3) may represent imaginal disc primordia. Pharyngeal expression (PH) is a combination of clypeolabrum and hypopharyngeal expression noted earlier. $(k)$ Dorsal view of the same embryo as in $i$ and $j$. Note individual expressing cells in the brain lobes $(\mathrm{BC})$. Expression in the fully differentiated trachea $(\mathrm{T})$ and hindgut $(\mathrm{H} 1)$ is evident. (1) Flattened preparation of early-stage 16 embryo. Expression within the telson (TL) now constitutes a ring around the presumptive anal pads.

and Serrev5-5, which are essentially indistinguishable from one another, appear unchanged when in homozygous or hemizygous condition. This result defines these alleles genetically as amorphic. However, since the $S \operatorname{rr}^{\text {rev2-3 }}$ allele complements the $B d^{G}$ mutation, the
Ser rev2-3 mutation is probably not a protein null allele. The complementation behavior of the Ser ${ }^{r e v 2-3}$ and $B d^{G}$ alleles suggests that Serrate protein units may undergo homotypic interactions. Thus, the $S^{\text {rev2-3 }}$ and $B d^{G}$ protein products may not be able to interact with them- 
selves but may interact with each other so that hybrid function(s) are restored.

Consistent with the defects observed in the cuticle and nervous system of $\mathrm{Ser}^{-}$embryos, Serrate transcripts are localized in complex patterns within these tissues; however, a precise correlation of Serrate mutant phenotypes and Serrate expression must await localization of the protein product. The abundant and widespread expression of Serrate transcripts in the segments that make up the embryonic head and thorax correlates well with the lack of embryonic head and thoracic structures commonly seen in $\mathrm{Ser}^{-}$embryos. Likewise, the pattern of Serrate expression in the ventral epidermis of the abdominal segments correlates with the frequently absent or improperly formed denticles. Although Serrate is expressed in a small number of cells within the CNS, the gross morphological defects observed in the CNS of Serembryos may reflect contributions from two components. The first is the loss of Serrate CNS expression itself, and the second may be a consequence of mechanical stresses (e.g., lack of germ-band retraction) imposed by an improperly differentiating epidermis.

In the course of examining the embryonic phenotypes associated with Serrate lethal mutations, we noticed their similarity to those produced by several alleles of the gene coding for the Drosophila EGF receptor homolog known as DER, faint little ball or torpedo (Livneh et al. 1985; Price et al. 1989; Schejter and Shilo 1989). Although the presumed ligand(s) of the DER is not known, it seems reasonable to presume that mutations of the ligand will have a phenotype similar to mutations in the receptor. Mutations in the receptor might be expected to give rise to a single class of phenotypic severity, as the resultant phenotype would be dependent on the facility with which the receptor is able to interact with its ligand(s). In contrast, if the specificity of the receptor is not absolute, as is the case with the mammalian EGF receptor (for review, see Carpenter 1987), mutations in one ligand (of several competing ligands) might result in a variable phenotype. We note that a single Serrate embryonic lethal allele displays a variety of phenotypes, each of which is reminiscent of those produced by singular DER alleles (Clifford and Schüpbach 1989; Schejter and Shilo 1989). In spite of these intriguing correlations, it must be emphasized that any relationship between the DER and Serrate is, at this point, purely speculative. We do note, however, that there appears to be some colocalization of the Serrate RNA and the DER gene products early in embryogenesis, particularly in the head and epidermis; but as development proceeds, the expression patterns become clearly distinct (Zak et al. 1990).

\section{Materials and methods}

Drosophila cultures and strains

Cultures were maintained on standard cornmeal/molasses/agar Drosophila medium supplemented with active dry yeast and were raised at $25^{\circ} \mathrm{C}$. The red $\operatorname{Ser}^{D}, D f(3 R) \mathrm{Ser}^{+82 f 24}$, and $B d^{G}$ chromosomes were obtained from Peter Lewis. The red $\mathrm{Ser}^{D}$ chromosome was maintained in homozygous condition. The mutations $\mathrm{pll}^{11}, B d^{862.5}$, and $B d^{43.5}$ were generously provided by Kathryn Anderson. The Notch duplication CosP479 is an $\sim 40-$ kb P-element cosmid construct inserted into the third chromosome (Ramos et al. 1989). Other mutations and chromosomes have been described previously (Lindsley and Grell 1968).

\section{Mutagenesis}

Males aged 3-7 days and homozygous for the red $\mathrm{Ser}^{D}$ chromosome were irradiated with $\sim 4500 \mathrm{R}(150 \mathrm{kV}, 5 \mathrm{~mA}, 9.2-\mathrm{min}$ exposure; Torrex 150 Source, Torr X-Ray Corp.) and mated immediately to $C(1) A ; y / y^{2} Y 611$ or $C(1) D x ; y f / y^{2} Y 611$ virgin females. The $F_{1}$ males were scored for the absence of the $\operatorname{Ser}^{D}$ wing phenotype and mated to GIpl-3fz red e/Tm2, red $e$ virgin females to establish balanced $\mathrm{Ser}^{\mathrm{rev}} / \mathrm{TM} 2$, red e stocks.

Mutations used in this study are shown in Table 1.

\section{Embryonic phenotype analysis}

Cuticle preparations were according to the protocol of Wieschaus and Nüsslein-Volhard (1986) on embryos aged for a minimum of $24 \mathrm{hr}$ at $25^{\circ} \mathrm{C}$. Anti-HRP antibody staining of the embryonic nervous system (Jan and Jan 1982) was carried out using fluorescein-conjugated antibody (Cappel), as described in Preiss et al. (1988). CNS preparations of torpedo ${ }^{2 C 82}$ were used for comparison studies.

\section{Isolation of nucleic acids}

Genomic DNA was isolated as described in Pirrotta et al. (1983). Restriction enzyme cleavage, agarose gel electrophoresis, capillary transfer to nitrocellulose, and hybridization conditions were carried out according to standard procedures. DNA probes labeled with ${ }^{32} \mathrm{P}$ were prepared by random oligonucleotide priming, as described in Feinberg and Vogelstein (1983). Stage-specific total RNAs from a Canton-S strain were extracted in guanidinium thiocyanate essentially as described in Chirgwin et al. (1979). Pupal and adult RNAs were generously provided by A. Preiss (Preiss et al. 1988). Poly(A) ${ }^{+}$RNA was selected by serial passage over oligo(dT)-cellulose (Stratagene) according to Sambrook et al. (1989) and stored in ethanol. RNA was size fractionated in formaldehyde-agarose gels and blotted onto Nytran membrane (Schleicher \& Schuell) by capillary transfer. RNA was fixed to the membrane via UV crosslinking.

Two Drosophila genomic phage libraries (Preiss et al. 1985 R. Karess, unpubl.) were screened, and recombinant clones were isolated as described in Benton and Davis (1977). cDNAs in $\lambda \mathrm{gt} 10$ were isolated from the early pupal library of Poole et al. (1985). We isolated the Cl cDNA using the genomic EGFlike sequences from coordinates +1.5 to +4 (Fig. 3) as probe. Subsequently, we isolated the C3 cDNA using the $5^{\prime} 700-\mathrm{bp}$ terminal fragment of the $\mathrm{Cl} \mathrm{cDNA}$ as probe.

\section{Sequencing and analysis}

The EcoRI cDNA inserts from $\lambda \mathrm{gt} 10$ were subcloned directly into Bluescript KS + and KS - vectors (Stratagene). Singlestranded DNAs were produced according to the manufacturer's instructions. Both strands of the cDNAs were sequenced using the dideoxynucleotide chain-termination procedure (Sanger et al. 1977) and the Sequenase kit (U.S. Biochemicals). Sequence was obtained using the $\mathrm{Ml3}$ and reverse primers for these vectors. Additional sequence was obtained by generating internal deletions through the use of restriction sites within the 
Table 1. Mutations

\begin{tabular}{|c|c|c|}
\hline Mutation & Origin & Description \\
\hline $\operatorname{Ser}^{D}$ & $\begin{array}{l}\text { spontaneous; } \\
\text { information } \\
\text { (Lindsley and } \\
\text { Grell 1968) }\end{array}$ & $\begin{array}{l}\text { heterozygous } \\
\text { dominant wing } \\
\text { phenotype, } \\
\text { homozygous viable; } \\
\text { cytologically } \\
\text { normal }\end{array}$ \\
\hline$B d^{G}$ & $\begin{array}{l}\text { recovered among } \\
\text { heat-treated } \\
\text { flies } \\
\text { (Gottschewski } \\
\text { 1935) }\end{array}$ & $\begin{array}{l}\text { heterozygous } \\
\text { dominant wing } \\
\text { phenotype, } \\
\text { homozygous lethal, } \\
\text { cytologically } \\
\text { normal }\end{array}$ \\
\hline Ser rev3 & $\mathrm{X}$-ray (this study) & $\begin{array}{l}\text { homozygous lethal; } \\
\text { reciprocal } \\
\text { translocation of } 3 \mathrm{R} \\
(97 \mathrm{~F} \text { ) to } 2 \mathrm{R}(57)\end{array}$ \\
\hline Serrev2-3 & $\mathrm{X}$-ray (this study) & $\begin{array}{l}\text { homozygous lethal; } \\
\text { cytologically } \\
\text { normal. }\end{array}$ \\
\hline Ser ${ }^{r e v 2-11}$ & X-ray (this study) & $\begin{array}{l}\text { homozygous lethal; } \\
\text { inversion of } 97 \mathrm{~F} \text { to } \\
98 \mathrm{C}\end{array}$ \\
\hline Serrev5-5 & X-ray (this study) & $\begin{array}{l}\text { homozygous lethal; } \\
\text { cytologically } \\
\text { normal }\end{array}$ \\
\hline Serev6-1 & $\mathrm{X}$-ray (this study) & $\begin{array}{l}\text { homozygous lethal; } \\
\text { cytologically } \\
\text { normal }\end{array}$ \\
\hline$B d^{43.5}$ & $\begin{array}{l}\text { EMS (K. } \\
\text { Anderson, } \\
\text { unpubl.) }\end{array}$ & $\begin{array}{l}\text { homozygous lethal; } \\
\text { cytologically } \\
\text { normal }\end{array}$ \\
\hline$B d^{862.5}$ & $\begin{array}{l}\text { EMS (K. } \\
\text { Anderson, } \\
\text { unpubl.) }\end{array}$ & $\begin{array}{l}\text { homozygous lethal }_{i} \\
\text { cytologically } \\
\text { normal }\end{array}$ \\
\hline pll & $\begin{array}{l}\text { EMS (K. } \\
\text { Anderson, } \\
\text { unpubl.) }\end{array}$ & $\begin{array}{l}\text { homozygous lethal; } \\
\text { possible small } \\
\text { inversion within } \\
\text { the } 97 \mathrm{~F} \text { interval }\end{array}$ \\
\hline$T(Y: 3) R 128$ & $\begin{array}{l}\text { X-ray (Lindsley } \\
\text { et al. 1972) }\end{array}$ & $\begin{array}{l}\text { homozygous lethal; } \\
\text { reciprocal } \\
\text { translocation of } 3 \mathrm{R} \\
\{97 \mathrm{~F} \mid \text { to } \mathrm{Y} \text { short arm }\end{array}$ \\
\hline$D f(3 R) \mathrm{Ser}^{+82 f 24}$ & $\begin{array}{l}\text { X-ray (P. Lewis, } \\
\text { unpubl.) }\end{array}$ & $\begin{array}{l}\text { deficiency for } \\
\text { chromosome bands } \\
97 \mathrm{D} \text { to } 97 \mathrm{~F}-98 \mathrm{Al}\end{array}$ \\
\hline
\end{tabular}

Bluescript polylinker and the cDNA inserts. The remaining cDNA sequences that were not accessible by these methods were obtained by using synthetic primers (Research Genetics) complementary to the end of a previously determined sequence.

Sequences were entered by sonic digitizer and overlapping sequence compilation; manipulation, translation, and secondary structure prediction were accomplished by using the Intelligenetics PC-GENE. Open reading frame prediction and plotting were performed using the University of Wisconsin program CODONPREFERENCE (Gribshov et al. 1984). The SITES program (PCGENE) was used to predict the location of the signal sequence, transmembrane domain, EGF-like repeats, and phosphorylation sites.
Whole-mount in situ procedure

A modification of the whole-mount in situ procedure of D. Tautz (procedure 84a in Ashburner 1989) was used. The differences were as follows: Proteinase $\mathrm{K}$ (Boehringer Mannheim) treatment was $10-14$ min; $100 \mu l$ (rather than $10 \mu l$ ) of boiled probe was used; after washing the embryos with $1: 4$ hybridization buffer to PBT, they were washed twice in PBT for $20 \mathrm{~min}$ and then twice in $1 \times$ PBS, $0.1 \%$ BSA (globin-free, Sigma), $0.2 \%$ Triton X-100 for $20 \mathrm{~min}$; the antibody treatment was done in the same PBS, BSA, Triton solution at $4^{\circ} \mathrm{C}$ overnight; the embryos were washed four times in the PBS, BSA, Triton solution at room temperature; after the alkaline phosphatase reaction, embryos were dehydrated twice in $70 \%$ and $100 \%$ ethanol and then cleared in xylenes; the embryos were mounted in Permount (Sigma). Dissected embryos were rehydrated, dissected in $\mathrm{PBT}$, and mounted in $90 \%$ glycerol $[10 \%$ Tris- $\mathrm{HCl}$ at $\mathrm{pH} 8.0$, with $0.5 \% n$-propyl-galate [wt/vol; Sigma)].

The probe was made by runoff of a PCR reaction in $50 \mathrm{~mm}$ $\mathrm{KCl}, 10 \mathrm{mM}$ Tris- $\mathrm{HCl}$ (pH 8.3), $1.5 \mathrm{~mm} \mathrm{MgCl}, 0.01 \%$ (wt/vol) gelatin, $0.2 \mathrm{~mm}$ dATP, $0.2 \mathrm{~mm}$ dCTP, $0.2 \mathrm{~mm}$ dGTP, $0.15 \mathrm{~mm}$ dTTP, and $0.07 \mathrm{~mm}$ digoxigenin-11-dUTP (Boehringer Mannheim) using $150 \mathrm{ng}$ of custom synthesized primer and $\sim 400 \mathrm{ng}$ of linearized DNA. Probe was synthesized from cDNA coordinates 4826-3854; the opposite strand constituted the control probe and was synthesized from coordinates 4458 to 5015 /refer to Fig. 6). The conditions for the PCR thermal cycler were $95^{\circ} \mathrm{C}$ for $45 \mathrm{sec}, 55^{\circ} \mathrm{C}$ for $30 \mathrm{sec}$, and $72^{\circ} \mathrm{C}$ for $1 \mathrm{~min}$, which were run for 30 cycles. The probe was ethanol-precipitated twice and resuspended in $300 \mu$ l of hybridization solution.

\section{Acknowledgments}

We are grateful to Peter Lewis for stocks and genetic background concerning Serrate; we also thank Peter Hecht and Kathryn Anderson for their stocks and unpublished data from the $97 \mathrm{~F}$ region. Our thanks go to Benny Shilo for his help with mutant phenotype analysis and DER comparisons, to Mike Kuziora for advice with the whole-mount in situ technique, to Ruth Bryant, Wan Yu, and Jie-Xing Cai for technical assistance, and to Annette Preiss for the pupal and adult RNAs. We also thank our colleagues for their comments and thoughtful discussions on the manuscript. This research was partially supported by National Institutes of Health (NIH) grants GM 29093 and NS 26084 awarded to S.A.-T. R.J.F. and T.N.S. were supported by NIH postdoctoral fellowships 5 F32 GM11439 and 5 F32 GM11365, respectively. R.J.D. was supported by Anna Fuller postdoctoral fellowship 685 .

The publication costs of this article were defrayed in part by payment of page charges. This article must therefore be hereby marked "advertisement" in accordance with 18 USC section 1734 solely to indicate this fact.

\section{References}

Anson, D.S., K.H. Choo, D.J.G. Rees, F. Giannelli, K. Gould, J.A. Huddleston, and G.G. Brownlee. 1984. The gene structure of human anti-haemophilic factor IX. EMBO $I$. 3: $1053-1060$.

Appella, E., E.A. Robinson, S.J. Ullrich, M.P. Stoppelli, A. Corti, G. Cassani, and F. Blasi. 1987. The receptor-binding sequence of Urokinase. J. Biol. Chem. 242: 4437-4440.

Artavanis-Tsakonas, S. 1988. The molecular biology of the Notch locus and the fine tuning of differentiation in Drosophila. Trends Genet. 4: 95-100.

Ashburner, M. 1989. Drosophila: A laboratory manual. Cold 
Spring Harbor Laboratory Press, Cold Spring Harbor, New York.

Beachy, P.A., S.L. Helfand, and D.S. Hogness. 1985. Segmental distribution of bithorax complex proteins during Drosophila development. Nature 313: 545-550.

Belt, A.L. 1971. Research notes. Drosophila Inf. Serv. 46: 116.

Benton, W.D. and R.W. Davis. 1977. Screening lambda gt 10 recombinant clones by hybridizing to single plaques in situ. Science 196: 180-182.

Cagan, R.L. and D.F. Ready. 1989. Notch is required for successive cell decisions in the developing Drosophila retina. Genes Dev. 3: 1099-1112.

Campos-Ortega, J.A. and V. Hartenstein. 1985. The embryonic development of Drosophila melanogaster. Springer-Verlag, Berlin.

Carpenter, G. 1987. Receptors for epidermal growth factor and other polypeptide mitogens. Annu. Rev. Biochem. 56: 615649.

Cavener, D.R. 1987. Comparison of the consensus sequence flanking translational start sites in Drosophila and vertebrates. Nucleic Acids Res. 15: 1353-1361.

Chirgwin, J.M., A.E. Przybyla, R.J. MacDonald, and W.J. Rutter. 1979. Isolation of biologically active ribonucleic acid from sources enriched in ribonucleases. Biochemistry 18: 52945299.

Clifford, R.J. and T. Schüpbach. 1989. Coordinately and differentially mutable activites of torpedo, the Drosophila melanogaster homolog of the vertebrate EGF receptor gene. Genetics 123: $771-787$.

de la Concha, A., U. Dietrich, D. Weigel, and J.A. Campos-Ortega. 1988. Functional interactions of neurogenic genes in Drosophila melanogaster. Genetics 118: 499-508.

Doe, C.Q. and C.S. Goodman. 1985. Early events in insect neurogenesis. II. The role of cell interactions and cell lineage in the determination of neuronal precursor cells. Dev. Biol. 111: 206-219.

Engel, J. 1989. EGF-like domains in extracellular matrix proteins: Localized signals for growth and differentiation? FEBS 251: $1-7$.

Fehon, R.G., P.J. Kooh, I. Rebay, C.L. Regan, T. Xu, M.A.T. Muskavitch, and S. Artavanis-Tsakonas. 1990. Molecular interactions between the protein products of the neurogenic loci Notch and Delta, two EGF-homologous genes in Drosophila. Cell 61: 523-534.

Feinberg, A.P. and B. Vogelstein. 1983. A technique for radiolabeling DNA restriction endonuclease fragments to high specific activity. Anal. Biochem. 132: 6-13.

Furie, B. and B.C. Furie. 1988. The molecular basis of blood coagulation. Cell 53: 505-518.

Fyrberg, E.A., J.W. Mahaffey, B.J. Bond, and N. Davidson. 1983. Transcripts of the six Drosophila genes accumulate in a stage- and tissue-specific manner. Cell 33: 115-123.

Gottschewski, G. 1935. New mutants: Report of G. Gottschewski. Dros. Inf. Serv. 4: 14,16.

Gribshov, M., J. Devereux, and R.R. Burgess. 1984. The codon preference plot: Graphic analysis of protein coding sequences and prediction of gene expression. Nucleic Acids Res. 12: 539-549.

Jan, Y.L. and Y.N. Jan. 1982. Antibodies to horseradish peroxidase as specific neuronal markers in Drosophila and in grasshopper embryos. Proc. Natl. Acad. Sci. 79: 2700-2704.

Jürgens, G., E. Wieschaus, C. Nüsslein-Volhard, and H. Kluding. 1984. Mutations affecting the pattern of larval cuticle in Drosophila melanogaster. II. Zygotic loci on the third chromosome. Wilhelm Roux's Arch. Dev. Biol. 193: $283-295$.
Kidd, S., M.R. Kelley, and M.W. Young. 1986. Sequence of the Notch locus of Drosophila melanogaster: Relationship of the encoded protein to mammalian clotting and growth factors. Mol. Cell. Biol. 6: 3094-3108.

King, D.G. 1988. Cellular organization and peritrophic membrane formation in the cardia (proventriculus) of Drosophila melanogaster. J. Morphol. 196: 253-282.

Kopczynski, C.C., A.K. Alton, K. Fechtel, P.J. Kooh, and M.A.T. Muskavitch. 1988. Delta, a Drosophila neurogenic gene, is transcriptionally complex and encodes a protein related to blood coagulation factors and epidermal growth factor of vertebrates. Genes Dev. 2: 1723-1735.

Lehmann, R., F. Jimenez, U. Dietrich, and J.A. Campos-Ortega. 1983. On the phenotype and development of mutants of early neurogenesis in Drosophila melanogaster. Wilhelm Roux's Arch. Dev. Biol. 192: 62-74.

Lindsley, D.L. and E.H. Grell. 1968. Genetic variations of Drosophila melanogaster. Carnegie Inst. Wash. Publ. 627.

Lindsley, D.L., L. Sandler, B.S. Baker, A.T.C. Carpenter, R.E. Denell, J.C. Hall, P.A. Jacobs, G.L.G. Miklos, B.K. Davis, R.C. Gethmann, R.W. Hardy, A. Hessler, S.M. Miller, H. Nozawa, D.M. Parry, and M. Gould-Somero. 1972. Segmental aneuploidy and the genetic gross structure of the Drosophila genome. Genetics 71: 157-184.

Livneh, E., L. Glazer, D. Segal, J. Schlessinger, and B.-Z. Shilo. 1985. The Drosophila EGF receptor gene homolog: Conservation of both hormone binding and kinase domains. Cell 40: $599-607$.

Morgan, T.H., C.B. Bridges, and A.H. Sturtevant. 1925. The genetics of Drosophila. Bibliogr. Genet. 2: 1-226.

Nüsslein-Volhard, C., E. Wieschaus, and H. Kluding. 1984. Mutations affecting the pattern of larval cuticle in Drosophila melanogaster. I. Zygotic loci on the second chromosome. Wilhelm Roux's Arch Dev. Biol. 193: 267-282.

Olson, P.F., L.I. Fessler, R.E. Nelson, R.E. Sterne, A.G. Campbell, and J.H. Fessler. 1990. Glutactin, a novel Drosophila basement membrane-related glycoprotein with sequence similarity to serine esterases. EMBO I. 9: 1219-1227.

Pirrotta, V., C. Hadfield, and G.H.J. Pretorius. 1983. Microdissection and cloning of the white locus and the $3 \mathrm{~B} 1-3 \mathrm{C} 2$ region of the Drosophila X chromosome. EMBO J. 2: 927934.

Poole, S.J., L.M. Kauvar, B. Drees, and T. Kornberg. 1985. The engrailed locus of Drosophila: Structural analysis of an embryonic transcript. Cell 40: 37-43.

Poulson, D.F. 1937. Chromosomal deficiencies and embryonic development of Drosophila melanogaster. Proc. Natl. Acad. Sci. 23: 133-137.

Preiss, A., U.B. Rosenberg, A. Kienlin, E. Seifert, and H. Jäckle. 1985. Molecular genetics of Krüppel, a gene required for segmentation of the Drosophila embryo. Nature 313: 27-32.

Preiss, A., D.A. Hartley, and S. Artavanis-Tsakonas. 1988. The molecular genetics of Enhancer of split, a gene required for embryonic neural development in Drosophila. EMBO J. 7: 3917-3927.

Price, J.V., R.J. Clifford, and T. Schüpbach, 1989. The maternal ventralizing locus torpedo is allelic to faint little ball, an embryonic lethal, and encodes the Drosophila EGF receptor homolog. Cell 56: 1085-1092.

Ramos, R.G.P., B.G. Grimwade, K.A. Wharton, T.N. Scottgale, and S. Artavanis-Tsakonas. 1989. Physical and functional definition of the Drosophila Notch locus by $\mathrm{P}$ element transformation. Genetics 123: 337-348.

Rothberg, J.M., D.A. Hartley, Z. Walther, and S. Artavanis-Tsakonas. 1988. slit: An EGF-homologous locus in D. melano- 
gaster involved in the development of the embryonic central nervous system. Cell 55: 1047-1059.

Sambrook, J., E.F. Fritsch, and T. Maniatis. 1989. Molecular cloning: A laboratory manual, 2nd ed. Cold Spring Harbor Laboratory Press, Cold Spring Harbor, New York.

Sanger, F., S. Nicklen, and A.R. Coulson. 1977. DNA sequencing with chain-terminating inhibitors. Proc. Natl. Acad. Sci. 74: 5463-5467.

Schejter, E.D. and B.-Z. Shilo. 1989. The Drosophila EGF receptor homolog $(D E R)$ gene is allelic to faint little ball, a locus essential for embryonic development. Cell 56: 10931104.

Shellenbarger, D.L. and J.D. Mohler. 1978. Temperature-sensitive periods and autonomy of pleiotropic effects of $l(1) N^{t s 1}$, a conditional Notch lethal in Drosophila. Dev. Biol. 62: 432446.

Siegelman, M.H., I.C. Cheng, I.L. Weissman, and E.K. Wakeland. 1990. The mouse lymph node homing receptor is identical with the lymphocyte cell surface marker Ly-22: Role of the EGF domain in endothelial binding. Cell 61: 611-622.

Tautz, D. and C. Pfeifle. 1989. A non-radioactive in situ hybridization method for the localization of specific RNAs in Drosophila embryos reveals translational control of the segmentation gene hunchback. Chromosoma 98: 81-85.

Technau, G.M. and J.A. Campos-Ortega. 1986. Lineage analysis of transplanted individual cells in embryos of Drosophila melanogaster. II. Commitment and proliferative abilities of epidermal and neural cell precursors. Wilhelm Roux's Arch. Dev. Biol. 195: 445-454.

Tepass, U., C. Theres, and E. Knust. 1990. crumbs encodes an EGF-like protein expressed on apical membranes of Drosophila epithelial cells and required for organization of epithelia. Cell 61: 787-799.

Tomlinson, A. and D.F. Ready. 1987. Neuronal differentiation in the Drosophila ommatidium. Dev. Biol. 120: 366-376.

Vässin, H., J. Vielmetter, and J.A. Campos-Ortega. 1985. Genetic interactions in early neurogenesis of Drosophila melanogaster. J. Neurogenet. 2: 291-308.

Vässin, H., K.A. Bremer, E. Knust, and J.A. Campos-Ortega. 1987. The neurogenic gene Delta of Drosophila melanogaster is expressed in neurogenic territories and encodes a putative transmembrane protein with EGF-like repeats. EMBO I. 6: 3431-3440.

Welshons, W.J. 1956. Dosage experiments with split mutants in the presence of an enhancer of split. Dros. Inf. Serv. 30: $157-158$.

- 1965. Analysis of a gene in Drosophila. Science 150: $1122-1129$.

Wharton, K.A., K.M. Johansen, T. Xu, and S. Artavanis-Tsakonas. 1985. Nucleotide sequence from the neurogenic locus Notch implies a gene product that shares homology with proteins containing EGF-like repeats. Cell 43: 567581.

Wieschaus, E. and C. Nüsslein-Volhard. 1986. Looking at embryos. In Drosophila. A practical approach (ed. D.B. Roberts|, pp. 199-227. IRL Press, Oxford.

Wieschaus, E., C. Nüsslein-Volhard, and G. Jürgens. 1984. Mutations affecting the pattern of larval cuticle in Drosophila melanogaster. II. Zygotic loci on the X-chromosome and fourth chromosome. Wilhelm Roux's Arch. Dev. Biol. 193: $296-307$.

Xu, T., I. Rebay, R.J. Fleming, T.N. Scottgale, and S. ArtavanisTsakonas. 1990. The Notch locus and the genetic circuitry involved in early Drosophila neurogenesis. Genes Dev. 4: 464-475.

Yochem, J., K. Weston, and I. Greenwald. 1988. The Caenor- habditis elegans lin-12 gene encodes a transmembrane protein with overall similarity to Drosophila Notch. Nature 335: $547-550$.

Zak, N.B., R.J. Wides, E.D. Schejter, E. Raz, and B.-Z. Shilo. 1990. Localization of the DER/flb protein in embryos: Implications on the faint little ball lethal phenotype. Development 109: 865-874. 


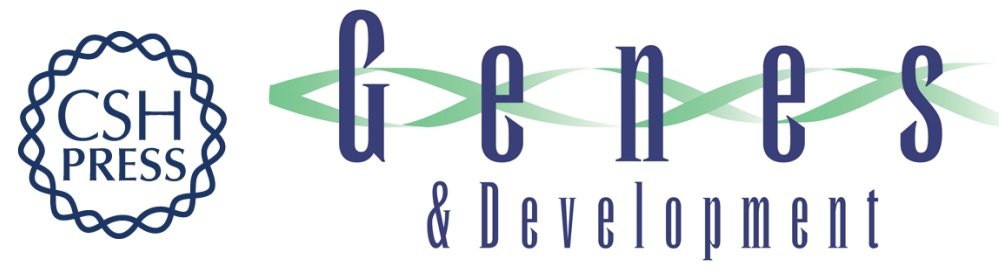

\section{The gene Serrate encodes a putative EGF-like transmembrane protein essential for proper ectodermal development in Drosophila melanogaster.}

R J Fleming, T N Scottgale, R J Diederich, et al.

Genes Dev. 1990, 4:

Access the most recent version at doi:10.1101/gad.4.12a.2188

References This article cites 56 articles, 14 of which can be accessed free at:

http://genesdev.cshlp.org/content/4/12a/2188.full.html\#ref-list-1

License

Email Alerting

Service

Receive free email alerts when new articles cite this article - sign up in the box at the top right corner of the article or click here.

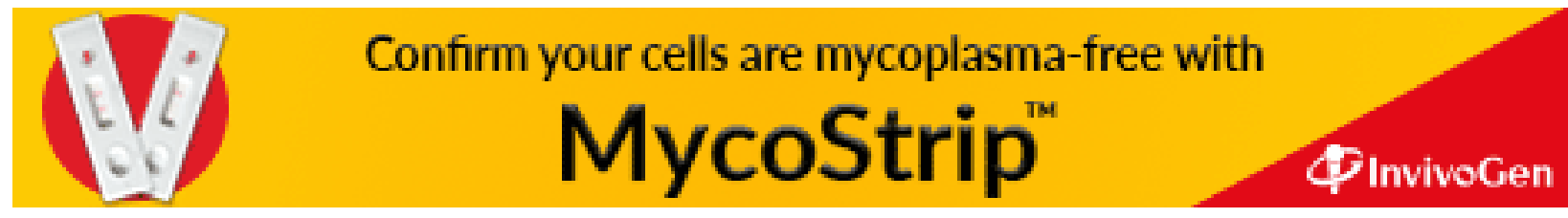

